\title{
Nickel isotopic composition of the mantle
}

\author{
Louise Gall $^{\mathrm{a}, \mathrm{b}}$, Helen M. Williams ${ }^{\mathrm{c}}$, Alex N. Halliday ${ }^{\mathrm{b}}$, Andrew C. Kerr ${ }^{\mathrm{d}}$ \\ ${ }^{a}$ CIRES, University of Colorado, Boulder, Colorado 80309, USA \\ ${ }^{b}$ Department of Earth Sciences, University of Oxford, Oxford OX1 3JA, UK \\ ${ }^{c}$ Department of Earth Sciences, University of Cambridge, Cambridge CB2 3EQ, UK \\ ${ }^{d}$ School of Earth and Ocean Sciences, Cardiff University, Cardiff CF10 3AT, UK
}

\begin{abstract}
This paper presents a detailed high-precision study of Ni isotope variations in mantle peridotites and their minerals, komatiites as well as chondritic and iron meteorites. Ultramafic rocks display a relatively large range in $\delta^{60} \mathrm{Ni}$ (permil deviation in ${ }^{60} \mathrm{Ni} /{ }^{58} \mathrm{Ni}$ relative to the NIST SRM $986 \mathrm{Ni}$ isotope standard) for this environment, from $0.15 \pm 0.07 \%$ o to $0.36 \pm 0.08 \%$, with olivine-rich rocks such as dunite and olivine cumulates showing lighter isotope compositions than komatiite, lherzolite and pyroxenite samples. The data for the mineral separates shed light on the origin of these variations. Olivine and orthopyroxene display light $\delta^{60} \mathrm{Ni}$ whereas clinopyroxene and garnet are isotopically heavy. This indicates that peridotite whole-rock $\delta^{60} \mathrm{Ni}$ may be controlled by variations in modal mineralogy, with the prediction that mantle melts will display variable $\delta^{60} \mathrm{Ni}$ values due to variations in residual mantle and cumulate mineralogy. Based on fertile peridotite xenoliths and Phanerozoic komatiite samples it is concluded that the upper mantle has a relatively homogeneous $\mathrm{Ni}$ isotope composition, with the best estimate of $\delta^{60} \mathrm{Ni}_{\text {mantle }}$ being $0.23 \pm 0.06 \%$ ( 2 s.d.). Given that $>99 \%$ of the $\mathrm{Ni}$ in the silicate Earth is located in the mantle, this also defines the Ni isotope
\end{abstract}


composition of the Bulk Silicate Earth (BSE). This value is nearly identical to the results obtained for a suite of chondrites and iron meteorites (mean $\delta^{60} \mathrm{Ni} 0.26 \pm 0.12 \%$ and $0.29 \pm 0.10 \%$, respectively) showing that the BSE is chondritic with respect to its $\mathrm{Ni}$ isotope composition, with little to no $\mathrm{Ni}$ mass-dependent isotope fractionation resulting from core formation.

1. Introduction

2 Nickel is a first-row transition metal that, under mantle melting condi3 tions, behaves as a strongly compatible element. The Earth's upper mantle 4 has a mean Ni concentration of $2000 \mu \mathrm{g} / \mathrm{g}$, which means this reservoir con${ }_{5}$ tains $>99 \%$ of the silicate Earth's Ni inventory (e.g. McDonough and Sun, 6 1995; Palme and O'Neill, 2014). In mantle-derived rocks Ni is primarily con7 centrated in olivine, the dominant silicate mineral in the upper mantle. In 8 Mg-rich mantle olivine, $\mathrm{Ni}^{2+}$ substitutes for $\mathrm{Mg}^{2+}$ in octahedral coordination, 9 leading to olivine $\mathrm{Ni}$ concentrations of around $3000 \mu \mathrm{g} / \mathrm{g}$ (e.g. Sato, 1977;

Stosch, 1981; Deer et al., 1982; Witt-Eickschen and O’Neill, 2005). Spinel is the only other mantle mineral that can accommodate similar amounts of $\mathrm{Ni}$, also predominantly in octahedral coordination (Stosch, 1981; WittEickschen and O’Neill, 2005). However, as the modal abundance of spinel in upper mantle lithologies is $<5 \%$, its impact on the mantle $\mathrm{Ni}$ budget is minor. Orthopyroxene is the second most common mineral in the upper mantle and 
can hold smaller, but significant, amounts of $\mathrm{Ni}(<1000 \mu \mathrm{g} / \mathrm{g})$, substituting into octahedral coordination space for $\mathrm{Mg}$ or Fe in the orthopyroxene lattice structure (Stosch, 1981; Deer et al., 1982; Witt-Eickschen and O’Neill, 2005). Nickel can also be found in lower concentrations $(<500 \mu \mathrm{g} / \mathrm{g})$ in clinopyroxene and garnet, also situated in octahedral coordination in both minerals (Witt-Eickschen and O'Neill, 2005). Although the hosts of Ni in the lower mantle are less well constrained, $\mathrm{Ni}$ has been observed to be concentrated in ferropericlase inclusions within diamonds, where it is present in amounts of 1-2.5 wt.\% (Kaminsky, 2012). Nickel has also been found in its native form (Kaminsky, 2012), which is potentially due to disproportionation of magneioswustite into bridgemanite which produces Fe-Ni metal (Frost et al., 2004; Wade and Wood, 2005; Williams et al., 2012).

8 Nickel stable isotopes are a relatively new geochemical tracer that has not been evaluated in detail in terrestrial high-temperature environments. A number of studies have attempted to quantify the degree of $\delta^{60} \mathrm{Ni}$ (permil deviation in ${ }^{60} \mathrm{Ni} /{ }^{58} \mathrm{Ni}$ relative to the NIST SRM $986 \mathrm{Ni}$ isotope standard) variation in igneous rocks, including mantle derived materials (Cameron et al., 2009; Steele et al., 2011; Gall et al., 2012, 2013; Gueguen et al., 2013; Chernonozhkin et al., 2015; Ratié et al., 2015; Estrade et al., 2015). However, most 
of these data are limited to rock standards or reference materials, and no systematic Ni stable isotope study of mantle rocks has been published. Other work on Ni stable isotopes in high-temperature environments has focused on meteorites (Cook et al., 2007; Moynier et al., 2007; Steele et al., 2011, 2012) and magmatic sulphide ore bearing bodies (Hofmann et al., 2014), while a number of studies have focused on the application of $\mathrm{Ni}$ isotopes in low temperature geochemistry (e.g. Porter et al., 2014; Cameron and Vance, 2014; Wasylenki et al., 2015; Ratié et al., 2015; Estrade et al., 2015). Published Ni isotope compositions for igneous rocks range between -0.1 and $0.3 \%$ in $\delta^{60} \mathrm{Ni}$ (e.g. Cameron et al., 2009; Gueguen et al., 2013). This study investigates this surprisingly large range in isotope composition for a high-temperature environment. Our aim is to better define the Ni isotope composition of the mantle by presenting data from peridotites, komatiites and mantle mineral separates, and to discuss these in the context of published whole-rock data. Finally, we aim to compare the isotope composition of the Bulk Silicate Earth (i.e. the mantle) with that of meteorites, to estimate the impact of core formation on the $\mathrm{Ni}$ isotope system on Earth. For this chondrite and iron meteorite data are presented and compared with existing data on such materials. 


\section{Sample selection}

\subsection{Mantle xenoliths, peridotites and mineral separates}

Most of the ultramafic xenoliths analysed in this study are from the Neogene volcanic province in Northern Tanzania, a part of the eastern Rift Valley of East Africa. These samples were selected for this study as they have been well characterised for a range of elemental and isotopic tracers and because they represent ancient sub continental lithospheric mantle. The majority of these samples were collected from the Lashaine volcano, an area famous for carbonatite lavas and the presence of ultramafic xenoliths similar to those from kimberlites (e.g. Dawson et al., 1970; Cohen et al., 1984; Dawson, 2002). The samples comprise two garnet lherzolites (BD730 and BD1355), three spinel harzburgites (BD774, BD822 and BD1542) and one alkaline pyroxenite (BD744). The garnet peridotites consist of varying proportions of red to purple garnet, emerald green clinopyroxene, orthopyroxene and magnesiumrich olivine ( Fog $_{90}$ for olivine from BD730), the latter without any signs of serpentinisation (Dawson et al., 1970). The spinel peridotites contain a much higher percentage of olivine (80-90 vol.\% compared to $50-65$ vol.\% in the garnet peridotites) and lower amounts of orthopyroxene (5-12 vol.\% versus 20-40 vol.\% in the garnet peridotites), but similar amounts of clinopyrox- 
73

74

ene (1-3 vol.\% only in both groups) (Dawson et al., 1970; Reid et al., 1975;

Rhodes and Dawson, 1975). The pyroxenite sample consists of rounded ironrich olivine $\left(\mathrm{Fo}_{84}\right)$, opaque phases (mainly chromite and magnetite), and clinopyroxene, surrounded by mica (Dawson and Smith, 1972). Other mantle rocks samples analysed were a kimberlite hosted garnet lherzolite xenolith from the Balfontain Mine in South Africa (e.g. Carswell and Dawson, 1970) and a dunite from the Appalachian peridotite massif in Jackson County, N. Carolina, USA (e.g. Kulp and Brobst, 1954; Stueber, 1969). These samples were both provided by the Natural History Museum in London. For interlaboratory comparison we have also analysed the USGS reference materials DTS-1 and PCC-1 for their Ni isotope compositions. The reference sample PCC-1 is a partially serpentinised harzburgite from the Cazadero ultramafic massif, California, USA (Flanagan, 1967, 1969; Barnes and O’Neil, 1969) and DTS-1 is a dunite sample from the Twin Sisters Mountain, Washington, USA (Flanagan, 1967, 1969; Ragan, 1963).

In addition to whole rock mantle xenoliths we have analysed mineral separates from mantle xenoliths from of the Cameroon Line, which have previously been studied for Fe isotopes (Williams et al., 2004, 2005). The goal of these analyses was to determine the magnitude of inter-mineral $\mathrm{Ni}$ 
isotope fractionation and to compare the behaviour of $\mathrm{Ni}$ and $\mathrm{Fe}$ isotopes. The analysed samples comprise three spinel lherzolites from different volcanic centres in Cameroon: (1) olivine from C235A, Lake Baronbi Mbo near Mount Cameroon; (2) orthopyroxene from C273Q, Lake Enep near Oku in Cameroon; (3) olivine, orthopyroxene and clinopyroxene from P13, Ngaoundere Plateau, Cameroon (Lee et al., 1996). Two mineral megacrysts, garnet and clinopyroxene, were also analysed from sample N12, a harzburgite from the Biu Plateau in Nigeria. The three analysed spinel lherzolites contain 45-65 vol.\% olivine, 25-35 vol.\% orthopyroxene, 10-15 vol.\% clinopyroxene and $<5$ vol.\% spinel, while the Biu Plateau harzburgite contains 55-60 vol.\% olivine and 40-45 vol.\% orthopyroxene as well as small amounts $(<5 \%)$ of clinopyroxene and garnet (Lee et al., 1996). In a previous study of the same samples, Williams et al. (2005) concluded that the minerals were largely in inter-mineral Fe isotopic equilibrium, based on the constant offsets between the different phases from mantle xenoliths and massif samples.

\subsection{Komatiites}

Komatiites are generated by extremely high-degree (35 to 50\%) partial melting of the mantle. The occurrence of komatiites is largely restricted to Archean and early Proterozoic terranes, which is considered to reflect the 

${ }_{127}$ by Hibbert et al. (2012). (Savage et al., 2015).

higher ambient mantle temperatures at these times (e.g. Nisbet et al., 1993; Arndt et al., 2008). As large-degree partial melts komatiites approximate the chemical composition of their source, and have thus been used to constrain the composition of the mantle for Fe isotopes (e.g. Dauphas et al., 2010; Hibbert et al., 2012), Mo isotopes (Greber et al., 2015) and $\mathrm{Cu}$ isotopes

The komatiites of Gorgona Island, Colombia, are the only documented occurrence of Phanerozoic komatiite (dated at 90 Ma; Walker et al., 1999; Sinton et al., 1998). Being the youngest known example of komatiite these are also the texturally least altered specimens of this rock type available and have been well characterised in previous publications (e.g. Aitken and Echeverría, 1984; Arndt et al., 1997; Kerr et al., 1996; Kerr, 2005). The mineralogy of the Gorgona cumulates and komatiites consists of olivine, plagioclase, pyroxene, Cr-spinel and altered, devitrified glass, with the metamorphic grade not exceeding greenschist facies (Aitken and Echeverría, 1984). Some of the samples analysed in this study have previously been analysed for Fe isotopes 


\subsection{Meteorites}

For this study nine magmatic iron meteorites from six different meteorite classes were analysed (Negrillos and North Chile, IIA; Sikhote-Alin, IIB; Arispe, IC; Charcas and Henbury, IIIA; Clark County, IIIF; Gibeon and Duel Hill, IVA). Twelve chondrite meteorites from different classes were analysed, of which four were carbonaceous chondrites (Allende, CV3; Murchison, CM2; Orgueil, CI1; Ornans, CO3), two enstatite chondrites (Indarch, EH4;

Khaipur, EL6) and six ordinary chondrites (Kernouve, H6; Baratta, L3; Bremervorde, L4; Buderheim, L6; Parnallee, LL3; St. Severin, LL6). All but three meteorites analysed were provided by the Natural History Museum, London; the three remaining meteorites were supplied by the Smithsonian National Museum, Washington D.C.

\section{Methods}

A comprehensive description of our procedures for Ni separation and isotope analysis can be found in Gall et al. (2012) with only a summary of the most important aspects given here.

All peridotite, komatiite and chondrite whole-rock samples for this study were dissolved in high-pressure Teflon bombs to assure complete dissolution 
of all mineral phases. These samples were weighed into pre-cleaned Savillex high-pressure hexagon-cap vials and a mixture of concentrated $\mathrm{HNO}_{3}$ and $\mathrm{HF}$ $(\sim 1: 5)$ was added. The samples were then put in an oven (at $\left.140^{\circ} \mathrm{C}\right)$ for two days after which the dissolutions were complete without residue. The mineral separates were weighed into pre-cleaned Savillex beakers and dissolved in a 1:5 mixture of concentrated $\mathrm{HNO}_{3}$ and $\mathrm{HF}$ on a hotplate $\left(130^{\circ} \mathrm{C}\right)$ overnight. Following digestion, the all silicate samples were dried and treated first with concentrated $\mathrm{HNO}_{3}$ and then $6 \mathrm{M} \mathrm{HCl}$ to remove any remaining fluorides. To remove any contamination on the outer layers of the iron meteorites the solid samples were first polished with $\mathrm{SiC}$ paper and cleaned in MQ water, and then leached in cold $6 \mathrm{M} \mathrm{HCl}$ for $30 \mathrm{~min}$. This last step was repeated 3 times, after which $>90 \%$ of the samples still remained. The cleaned iron meteorites were dissolved in $6 \mathrm{M} \mathrm{HCl}$ on a hotplate $\left(120^{\circ} \mathrm{C}\right)$ overnight. Following complete dissolution, all samples were evaporated until dry and taken up in $6 \mathrm{M} \mathrm{HCl}$ before chromatography. A three stage column chromatographic technique was used to separate $\mathrm{Ni}$ from sample matrices, exploiting the ability of $\mathrm{Ni}$ to form strong complexes with firstly ammonia and secondly dimethylglyoxime. A final anion exchange cleanup column ensured removal of any remaining Fe. The full procedural blank from this separation technique was less than 3 
ng, which is negligible compared to the amounts of Ni processed per sample (1000-3000 ng). The yield for mantle rocks and meteorites was close to $100 \%$. We used the double-spike technique to ensure that any potential fractionation induced during the separation procedure was corrected for by spiking of all samples prior to chemical separation.

Nickel has five stable isotopes: ${ }^{58} \mathrm{Ni},{ }^{60} \mathrm{Ni},{ }^{61} \mathrm{Ni},{ }^{62} \mathrm{Ni}$ and ${ }^{64} \mathrm{Ni}$, with the respective abundances of $68.08 \%, 26.22 \%, 1.14 \%, 3.63 \%$ and $0.93 \%$ (Gramlich et al., 1989). A double-spike approach was used here for correction of instrumental mass bias, and, as mentioned above, isotopic fractionation during sample processing. The double spike consisted of $25: 75^{61} \mathrm{Ni}:{ }^{62} \mathrm{Ni}$ and was added to each sample at a sample:spike Ni ratio of 0.4 . The purified Ni solutions were analysed using a Nu Plasma II (Nu Instruments) high-resolution multi-collector inductively coupled plasma mass spectrometer (MC-ICPMS) at Oxford University. Sample solutions of $100 \mathrm{ng} / \mathrm{g}$ Ni were introduced into the plasma in $0.3 \mathrm{M}(2 \%) \mathrm{HNO}_{3}$ using a Nu Instruments DSN desolvator and a PFA concentric nebulizer (Elemental Scientific). Measurements consisted of 40 10-second integrations and baselines were measured by ESA deflection. The possible interference of ${ }^{58} \mathrm{Fe}$ on ${ }^{58} \mathrm{Ni}$ was corrected online through simultaneous measurement of ${ }^{57} \mathrm{Fe}$. All analyses were performed at medium mass 
resolution mode (resolving power, $\mathrm{m} / \Delta \mathrm{m} \approx 3000$ ) to ensure that any polyatomic interferences were resolved. The mean beam intensity obtained under these conditions were $\sim 3 \mathrm{~V}$ on mass 58 , or around $40 \mathrm{~V}$ per ppm Ni. The data reduction procedure of measured isotope ratios followed Siebert et al. $(2001)$

Most samples analysed during this study were digested twice and all processed solutions were analysed on at least 2 different occasions. Multiple full repeats and analyses of the USGS reference materials PCC-1 (15 individual analyses), BHVO-2 (35 analyses) and SCo-1 (16 analyses) gave a long term external reproducibility of $\pm 0.07 \%$ ( 2 s.d.) for silicate samples (Gall et al., 2012). All Ni isotope ratios reported here are presented as the ${ }^{60} \mathrm{Ni} /{ }^{58} \mathrm{Ni}$ ratio relative to the $\mathrm{Ni}$ isotope standard SRM 986 (NIST).

$$
\delta^{60} N i=\left[\frac{\left({ }^{60} N i /{ }^{58} N i\right)_{\text {sample }}}{\left({ }^{60} N i /{ }^{58} N i\right)_{S R M 986}}-1\right] \times 1000
$$

\section{Results}

All results are given in Tables 1-3. The number of replicate analyses (n)

for each sample is given in these tables and all uncertainties are reported as 2 standard deviations (2 s.d.) unless noted otherwise. 
Results of peridotite and komatiite analyses can be found in Table 1 . The Ni isotope composition of the two USGS peridotite reference materials DTS-1 and PCC-1 were determined to be $-0.08 \pm 0.07 \%$ and $0.14 \pm 0.06 \%$ respectively. Our values for these rock standards are in excellent agreement with previously published data reported by Gueguen et al. (2013) (DTS-1: $-0.07 \pm 0.05 \%$ and PCC-1: $0.12 \pm 0.05 \%$ o) and Chernonozhkin et al. (2015) (DTS-1: $-0.07 \pm 0.01 \%$ and PCC-1: $0.17 \pm 0.05 \%$ ). There is a discrepancy with the $\delta^{60} \mathrm{Ni}$ for PCC-1 reported by Cameron et al. (2009), who obtain a value nearly $0.20 \%$ heavier $(0.34 \pm 0.08 \%$ o $)$. As this heavy value has not been replicated by either this study, Gueguen et al. (2013) or Chernonozhkin et al. (2015) it is not included in the discussion nor in the comparison of new and published data in Fig. 1. To examine the effect of low- vs. high-pressure dissolution on the $\mathrm{Ni}$ isotope composition separate samples of the DTS-1 dunite were dissolved using the different digestion techniques. No difference in $\delta^{60} \mathrm{Ni}$ (within error) were seen between the different types of digestions of this sample, even though the spinels were clearly still undissolved in the low-pressure experiments.

The eight ultramafic samples display $\delta^{60} \mathrm{Ni}$ ranging from 0.15 to $0.36 \%$. The dunite (NHM-1) exhibit the lowest $\delta^{60} \mathrm{Ni}$ of $0.15 \pm 0.07 \%$. Two of the 
three harzburgite samples also display low values of $0.18 \pm 0.07 \%$ (BD1542) and $0.20 \pm 0.03 \%$ (BD822), while the last harzburgite (BD774) has a higher $\delta^{60} \mathrm{Ni}$ of $0.28 \pm 0.06 \%$. The two volcanic lherzolite xenoliths possess slightly higher $\delta^{60} \mathrm{Ni}$ than dunite, of $0.23 \pm 0.06 \%$ (BD730) and $0.25 \pm 0.06 \%$ (BD1355), and the kimberlite lherzolite xenolith (NHM-2) having a very similar $\delta^{60} \mathrm{Ni}$ of $0.22 \pm 0.06 \%$. The single analysed pyroxenite xenolith (BD744) have a significantly higher $\delta^{60} \mathrm{Ni}$ than all other samples: $0.36 \pm 0.08 \%$. The mean $\delta^{60} \mathrm{Ni}$ value of all peridotite xenolith samples is $0.22 \pm 0.08 \%$ (i.e. excluding the pyroxenite and dunite samples).

The Gorgona samples show a similar range in $\delta^{60} \mathrm{Ni}$ to the peridotite xenoliths, with $\delta^{60} \mathrm{Ni}$ values ranging from 0.15 to $0.26 \%$. The three olivine cumulate samples display lower $\delta^{60} \mathrm{Ni}$ values of $0.15 \pm 0.05 \%, 0.19 \pm 0.04 \%$ o and $0.22 \pm 0.04 \%$ respectively, while the two komatiite samples show slightly higher $\delta^{60} \mathrm{Ni}$ of $0.24 \pm 0.06 \%$ and $0.26 \pm 0.07 \%$.

The $\delta^{60} \mathrm{Ni}$ for each mineral separate is given in Table 2 and reveals mineralogical differences. Olivine ranges from $0.14 \pm 0.05 \%$ for sample C273Q to $0.17 \pm 0.05 \%$ for P13, whereas orthopyroxenes show much lower values of $-0.04 \pm 0.04 \%(\mathrm{C} 235 \mathrm{~A})$ and $-0.02 \pm 0.06 \%$ (P13). The single lherzolite clinopyroxene separate analysed displays an extremely high $\delta^{60} \mathrm{Ni}$ value of 
$2.83 \pm 0.11 \%$, while the harzburgite clinopyroxene sample also displays a heavy, though less extreme, value of $0.42 \pm 0.08 \%$. The sole garnet analysed shows an intermediate $\delta^{60} \mathrm{Ni}$ of $0.30 \pm 0.06 \%$.

Results of meteorite analyses are given in Table 3. The Ni isotope composition of eight of the nine iron meteorites analysed show a range in $\delta^{60} \mathrm{Ni}$ from $0.20 \%$ to $0.36 \%$, with no systematic differences between sample groups. The last iron meteorite, Duel Hill (IVA), displays a significantly lighter isotope composition of $-0.06 \pm 0.06 \%$. Chondrite meteorites display a range in $\delta^{60} \mathrm{Ni}$ similar to that of iron meteorites. Of the carbonaceous chondrites the CI1 chondrite Orgueil show the lowest value of $0.18 \pm 0.04 \%$, Allende and Murchison (CV3 and CM2, respectively) possess very similar values of $0.24 \pm 0.07 \%$ and $0.23 \pm 0.07 \%$, respectively, whereas Ornans (CO3) show a slightly higher value of $0.29 \pm 0.08 \%$. The two enstatite chondrites Indarch (EH4) and Khaipur (EL6) have very similar values of $0.28 \pm 0.09 \%$ and $0.29 \pm 0.08 \%$. The most variation in $\delta^{60} \mathrm{Ni}$ within chondrite meteorites is found amongst ordinary chondrites. This group of six samples (two each from the H, L and LL classes) display $\delta^{60} \mathrm{Ni}$ values varying between $0.16 \pm 0.05 \%$ o and $0.51 \pm 0.07 \%$. 


\section{Discussion}

\subsection{Evidence for mineralogical control on $\delta^{60} \mathrm{Ni}$ variations in mantle rocks}

The data from mineral separates demonstrate a significant degree of high temperature $\mathrm{Ni}$ isotope fractionation in mantle rocks. The two orthopyroxene separates are isotopically light relative to the two olivine separates and both olivine and orthopyroxene separates are significantly lighter than both clinopyroxene and garnet (Fig. 1). Nickel is situated in the same lattice position (replacing $\mathrm{Mg}$ in octahedral coordination) in all the analysed minerals, so the different isotope compositions of minerals is unlikely to be due to crystallographic differences. To investigate inter-sample mineral relationships all main three silicate phases (olivine, orthopyroxene and clinopyroxene) of the spinel lherzolite sample P13 were analysed. Analyses of dunite DTS-1 digested in low-pressure beakers, with the spinels remaining undissolved, show no difference in $\delta^{60} \mathrm{Ni}$ from samples digested in high-pressure vessels. This indicates that spinel may not have a large impact on the sample $\mathrm{Ni}$ isotope composition. So although the co-existing spinel $(\sim 5 \%$ modal mineralogy of sample, Lee et al. (1996); Table 2) was not analysed for sample P13 an approximative Ni isotope composition of the bulk sample was calculated as $\delta^{60} \mathrm{Ni}=0.25 \pm 0.13 \%$ (the comparatively large error on this value reflects the 
propagation of errors on individual mineral separate analyses). This value is consistent with data from other peridotites. The same mineral separates from sample P13 were also analysed for their Fe isotope composition by Williams et al. (2005) (see supplementary material for $\delta^{57} \mathrm{Fe}$ values), who determined them to be in inter-mineral isotope equilibrium in terms of Fe isotopes. The bulk $\delta^{57} \mathrm{Fe}$ for this sample, calculated from the mineral separate data, was determined to be $\delta^{57} \mathrm{Fe}_{P 13}=0.15 \pm 0.18 \%$, which also overlaps with mantle $\delta^{57}$ Fe values (e.g. Dauphas et al., 2009). Furthermore, the trace-element abundances of P13 demonstrate this sample's primitive, unmetasomatised nature (Lee et al., 1996). Therefore, there is no indication that this sample or its calculated bulk isotope composition is anomalous.

It is possible that the extremely heavy isotope composition of the P13 clinopyroxene represents kinetic isotope fractionation rather than equilibrium fractionation. While Fe isotopes do appear to record inter-mineral isotope equilibrium (within error), the mass balance of $\mathrm{Fe}$ and $\mathrm{Ni}$ is very different in mantle rocks, making it possible for kinetic isotope effects to be preserved for Ni isotopes alone. However, considering that the equilibration temperature for sample P13 has been calculated to $>800^{\circ} \mathrm{C}$ (Lee et al., 1996) it is unlikely that kinetic isotope effects would be preserved in individual minerals. The 
very heavy isotope composition of clinopyroxene from P13 could also have been skewed by undiscovered mineral inclusions present in the sample. Such inclusions would need to be both very Ni-rich and to possess an extreme isotope composition to have an effect on the sample. As the dissolution of this sample was not performed in a high-pressure vial it is unlikely that any spinel inclusion was accidentally dissolved. Similarly, published data have shown that sulphides are isotopically very light (as low as $-1.03 \%$; Gueguen et al., 2013; Hofmann et al., 2014). One possibility is a base metal grain, as these are the only phases with significant $\mathrm{Ni}$ that are also predicted to be isotopically heavy with respect to silicate (Lazar et al., 2012). However, in this case, the sample would have displayed anomalously high $\mathrm{Ni}$ concentrations, which was not observed. Moreover, these are extensively studied samples and the presence of metal grains would have been apparent in trace element analyses (Lee et al., 1996) or the Fe isotope study by Williams et al. (2005). Additionally, as the other clinopyroxene analysis (from harzburgite N12; $0.42 \pm 0.08 \%$ ) and the analysis of the pyroxenite xenolith (BD744; $0.36 \pm 0.08 \%$ o $)$ both show significantly heavier values than all other minerals and bulk rocks, it seems likely that an isotopically heavy composition for clinopyroxene in mantle rocks is normal. The limited data and variable degree 
of $\mathrm{Ni}$ isotope fractionation between clinopyroxene and other silicate minerals make it premature to determine the causes of the $\mathrm{P} 13$ clinopyroxene isotope composition. Nonetheless, its heavy composition effectively demonstrates the potential impact of the modal mineralogy of the fractionating assemblages on the bulk Ni isotope compositions of mantle rocks. This suggests significant implications for the Ni isotope compositions of mantle partial melts derived from depleted (olivine-dominated) versus enriched (pyroxene-dominated, potentially as a consequence of surface recycling) lithologies. The nickel stable isotope compositions of primitive melts may therefore, in combination with other tracers, be a useful tracer of mantle source lithology.

Figure 2 shows the modal mineral abundances of olivine, orthopyroxene and clinopyroxene in the Tanzanian xenolith samples plotted against their whole-rock $\delta^{60} \mathrm{Ni}$. There is a striking positive correlation between wholerock $\delta^{60} \mathrm{Ni}$ and the modal abundance of clinopyroxene, with the isotopically heaviest sample containing the most clinopyroxene. The figure shows that the heavy harzburgite (BD774) contains 2-3 times as much clinopyroxene as the other two harzburgite samples. This suggests that, although the majority of $\mathrm{Ni}$ in mantle rocks is located in olivine, whole-rock Ni isotope compositions are strongly dependent on the proportion of clinopyroxene. From the very 
strong preference of clinopyroxene for isotopically heavy Ni (Fig. 1, Table 2) this is entirely understandable.

A compilation of all the available $\delta^{60} \mathrm{Ni}$ data of ultramafic rocks divided according to sample type is also shown in Fig. 1 (smaller triangles). Previously published data for unaltered peridotite samples are all analyses of the rock reference material PCC-1, DTS-1, DTS-2 (USGS) and JP-1 (GJS) (Steele et al., 2011; Gueguen et al., 2013; Chernonozhkin et al., 2015). The USGS reference sample PCC-1 is a harzburgite (Cazadero ultramafic massif, California) and DTS-1, -2 (Twin Sisters Mountain, Washington) and JP-1 (Horoman dunite, Japan; Imai et al., 1995) are dunites. All these reference materials are from Alpine-type ultramafic massifs, similar to the Appalachian dunite NHM-1 analysed during this study. All the analyses of dunites and most of the harzburgites show these depleted olivine-rich rock types have light $\mathrm{Ni}$ isotope compositions relative to lherzolites (Fig. 1). This is entirely consistent with our mineral $\mathrm{Ni}$ isotope data, and, as discussed above, highlights the potential of $\mathrm{Ni}$ isotopes as a tracer of mantle mineral heterogeneity. However, an alternative possibility that must be considered is that the low $\delta^{60} \mathrm{Ni}$ signatures of the peridotite massif samples (PCC-1, DTS-1 and -2, JP-1 and NHM-1) reflect secondary alteration processes, such as serpentinisation. 
To evaluate this possibility we have also plotted published data for serpentinised peridotites in Fig. 1 (smaller circles). These samples come from four different locations: the Logatchev hydrothermal field on the mid-Atlantic ridge (Gueguen et al., 2013), the Cerro Matoso laterite deposit, Colombia (Gall et al., 2013), the Barro Alto ultramafic massif, Brazil (Ratié et al., 2015), and the ophiolitic belt in Albania (Estrade et al., 2015). All but one of these samples display $\delta^{60} \mathrm{Ni}$ similar to fresh peridotite xenoliths, varying between $0.09 \%$ and $0.32 \%$. These data suggest that $\delta^{60} \mathrm{Ni}$ in peridotites is not significantly affected by serpentinization and that such processes cannot be responsible for the large range in $\delta^{60} \mathrm{Ni}$ found in mantle rocks. It is furthermore possible for other processes, such as refertilisation and recycling, to have influenced the Ni isotope composition of peridotites. However, metasomatic processes would enrich peridotites in mainly incompatible elements. As $\mathrm{Ni}$ is a very compatible element in mantle rocks it is unlikely that peridotite $\mathrm{Ni}$ isotope composition should be affected by metasomatism.

Our data demonstrate that whole-rock $\delta^{60} \mathrm{Ni}$ variations most likely reflect mineral isotope fractionation effects and also provide an indication of how this affects the isotope composition of bulk rocks and melt depleted residues. Due to the non-modal nature of partial melting processes and the preferential 
contribution of clinopyroxene to the melting assemblage, isotopically heavy clinopyroxene could contribute to melt extraction generating depleted mantle residues with light Ni isotope composition relative to fertile mantle material. This could be the reason for olivine-rich cumulate komatiites from Gorgona displaying lower $\delta^{60} \mathrm{Ni}$ relative to the primitive komatiite samples from the same suite, and that dunites and harzburgites appear to be isotopically lighter than lherzolites (Fig. 1). Therefore, a best estimate of the primitive mantle $\delta^{60} \mathrm{Ni}$ may be defined by the composition of the three lherzolites (two from Lashaine volcano and one from a South African kimberlite) and the two Gorgona komatiite samples. The suitability of these samples as a base for estimating the $\mathrm{Ni}$ isotope composition of the BSE is further supported by their overlap with the komatiite samples analysed. That these two sets of rock types are completely within error of each other broadly supports homogenous distribution of $\mathrm{Ni}$ isotopes in the mantle. This yields a $\delta^{60} \mathrm{Ni}_{\text {mantle }}$ value of $0.23 \pm 0.06 \%$ (mean and 2 s.d. of all measurements of these samples; $\mathrm{n}=25)$. The calculated bulk rock $\delta^{60} \mathrm{Ni}$ for the fertile lherzolite sample $\mathrm{P} 13(0.25 \pm 0.13 \%)$ is also in excellent agreement with this narrower $\delta^{60} \mathrm{Ni}$ estimate for the mantle. Published Fe isotope data exist for the Gorgona komatiites (data from 
Hibbert et al., 2012) the ultramafic reference materials PCC-1, DTS-2 (from

Dauphas et al., 2009), DTS-1 and JP-1 (from Poitrasson et al., 2004) and for the mineral separates from spinel lherzolite P13 (from Williams et al., 2005). When these data are plotted against $\delta^{60} \mathrm{Ni}$ a clear positive relationship is observed for all but one of the whole-rock samples $\left(\mathrm{R}^{2}=0.936\right.$; Fig. 3$)$. The isotopically heaviest samples for both $\mathrm{Ni}$ and $\mathrm{Fe}$ are the komatiites, while olivine-rich cumulates and rocks have lower $\delta^{60} \mathrm{Ni}$ and $\delta^{57} \mathrm{Fe}$ values.

The heavy Fe isotope compositions of mantle partial melts relative to peridotites has previously been interpreted in terms of partial melting and the preferential partitioning of isotopically heavy Fe into the melt phase (e.g. Williams et al., 2005; Dauphas et al., 2010, 2014). Interestingly, while Fe and $\mathrm{Ni}$ isotopes appear to show similar behaviour, the partitioning of Fe isotopes between melt and residue has been interpreted to be at least in part a function of the more incompatible nature of isotopically heavy $\mathrm{Fe}^{3+}$ (Williams et al., 2005; Dauphas et al., 2010, 2014). As Ni is not a redox-sensitive element under the conditions of mantle partial melting the strong correlation between Fe and $\mathrm{Ni}$ isotopes must therefore reflect other processes that do not relate to variations in oxidation state but which affect both isotope systems, such as variations in mantle melting lithology (e.g. Williams and Bizmis, 2014). The 
mineral separates (olivine and orthopyroxene) as well as the reconstructed composition of P13 are also plotted in Fig. 3. The calculated composition for this sample $\left(\delta^{60} \mathrm{Ni}_{P 13}=0.25 \pm 0.13 \%\right.$ and $\delta^{57} \mathrm{Fe}_{P 13}=0.15 \pm 0.18 \%$ ) plots together with the komatiites at the heavier end of the spectrum, another indication of this sample's fertility. The olivine separate from sample P13 plots along the trend next to the Gorgona olivine cumulates. However, the P13 orthopyroxene separate has a very low $\delta^{60} \mathrm{Ni}$ given its relatively high $\delta^{57} \mathrm{Fe}$ and thus does not plot on the main trend. On the other hand, the P13 orthopyroxene overlaps with the only whole-rock sample (DTS-1) that does not follow the general trend (Fig. 3), possibly indicating a higher prevalence of orthopyroxene in this sample. The $\delta^{57} \mathrm{Fe}$ of the P13 clinopyroxene separate is heavier than the values for olivine and orthopyroxene (see insert on Fig. 3 ), although due to its extremely high $\delta^{60} \mathrm{Ni}$ this mineral plots far from the general $\delta^{60} \mathrm{Ni}-\delta^{57} \mathrm{Fe}$ trend seen in Fig. 3. This may be indicative of isotopic disequilibrium between these phases, and future studies are required to confirm this. 
5.2. Isotope composition of the BSE, meteorites and Ni isotope fractionation during core formation

Given that $>99 \%$ of the $\mathrm{Ni}$ in the silicate Earth is located in the mantle, our value of $\delta^{60} \mathrm{Ni}_{\text {mantle }}$ of $0.23 \pm 0.06 \%$ is also the best estimate for the BSE. This is in good agreement with the previously suggested the value of $0.18 \pm 0.04 \%$ by Steele et al. (2011) and overlaps with the $0.15 \pm 0.24 \%$ o proposed by Cameron et al. (2009), while a third estimate of $0.05 \pm 0.05 \%$ o by Gueguen et al. (2013) is significantly lighter than all of these. All these studies however incorporate data for altered mantle and fractionated crustal rocks in their estimates. In contrast, the BSE estimate presented in this study is entirely based on fertile lherzolites and komatiites. Considering the evidence given here for a mineralogical control on the Ni isotope composition, this new estimate should represent a more accurate evaluation of the mean Ni isotope composition of the Bulk Silicate Earth.

Chondritic meteorites have previously been found to vary between between $0.18 \%$ and $0.33 \%$ (Fig. 5 - Cameron et al., 2009; Steele et al., 2012). The mass-dependent Ni isotope data of chondrites from Moynier et al. (2007) and Cook et al. (2007) are not included here, as almost all data from these studies are from measurements of chondrite metal separates and not whole- 
rock samples. The only exception to this are two measurements of bulk silicate samples in Moynier et al. (2007), one of Allende (CV3 chondrite) and one of Murchison (CM2 chondrite). These data are however significantly lighter (approximately $-0.2 \%$, Fig. 5) than both our and the Cameron et al. (2009) analyses of the same chondrite samples. This is probably due to the chemical separation technique used by Moynier et al. (2007), from which the Ni yield was only about $80 \%$ for silicates. As neither Moynier et al. (2007) nor Cook et al. (2007) used the double-spike technique, any stable isotope fractionation relating to chemical processing may not have been adequately corrected for. Additionally, errors on measurements performed in these two studies are significantly larger (estimated $\pm 0.14 \%$ on $\delta^{60} \mathrm{Ni}$ from Moynier et al. (2007); up to $\pm 0.80 \%$ on $\delta^{60} \mathrm{Ni}$ from Cook et al. (2007); Fig. 5) than errors for values presented here or other more recently published data, making direct comparisons difficult.

Our data for chondrite meteorites suggest that ordinary chondrites span a larger range of $\delta^{60} \mathrm{Ni}$ than carbonaceous or enstatite chondrites (Fig. 6). The isotopically heaviest of these sample is Bruderheim (L5), an ordinary chondrite that has been noted to have large mineralogical variations between the metallic and the silicate phase and a lower average olivine:pyroxene ratio 
than normal for chondrites (Duke et al., 1961). This makes it difficult to be certain that the $\delta^{60} \mathrm{Ni}$ measured here is representative of its bulk isotope composition, especially considering the above evidence of a mineralogical control on a sample's Ni isotope composition. Excluding this one heavy sample our mean $\delta^{60} \mathrm{Ni}$ value for chondrites becomes $0.26 \pm 0.12 \%$ (mean and 2 s.d. of all measurements of these samples; $\mathrm{n}=71$ ), which in excellent agreement with published values for similar samples (Cameron et al., 2009; Steele et al., 2012). Even excluding Bruderheim, ordinary chondrites still show a large variation in $\delta^{60} \mathrm{Ni}$. One possible explanation is an isotopically heavy metal component, as there appears to be a relationship between the metal content (LL, L, or $\mathrm{H}$ class) and the $\mathrm{Ni}$ isotope composition in ordinary chondrites (Fig. 6). This correlates well with high T metal-talc experiments by Lazar et al. (2012) that found indications for the metal phase being isotopically heavy relative to silicate.

Figure 6 also shows the $\mathrm{Ni}$ isotope composition of iron meteorites displayed according to their meteorite class. Apart from the one very light sample (Duel Hill, IVA, $-0.06 \pm 0.06 \%$ ) the data for iron meteorites are all within error and do not show any indications of their Ni isotope composition being dependent on class. This light outlier sample Duel Hill is likely anomalous, 
especially considering its low concentration of Ir and W, combined with very high concentrations of $\mathrm{Au}, \mathrm{As}, \mathrm{Cu}$ and Ni (Wasson and Richardson, 2001). This points towards this meteorite being a sample of core material that has undergone extreme degrees of fractional crystallisation, possibly crystallising very late from the parental magma (Wasson and Richardson, 2001). It is also possible that this sample does not at all belong to the main crystallisation sequence of the IVA parent body (Smoliar et al., 1996, based on Re-Os dating). Omitting the Duel Hill sample, our analyses of iron meteorites give a mean $\delta^{60} \mathrm{Ni}$ of $0.29 \pm 0.10 \%$ (mean and 2 s.d. of all measurements of these samples; $\mathrm{n}=47)$. The range in $\delta^{60} \mathrm{Ni}$ we observe for iron meteorites is in very good agreement with published data from Cameron et al. (2009); Steele et al. (2011); Gueguen et al. (2013) and Chernonozhkin et al. (2015). The Ni isotope data from Moynier et al. (2007) and Cook et al. (2007) are, again, spread over a much wider range than any other published data (Fig. 5), although this may in part be due to the wider range of samples, such as non-magmatic iron meteorites, included in these studies.

It has recently been shown that the BSE has a chondritic stable isotope composition for Mo (Greber et al., 2015) and Cr (Bonnand et al., 2015) (contrary to earlier suggestions by Hin et al., 2013; Burkhardt et al., 2014; 
Moynier et al., 2011). On the other hand the BSE is non-chondritic for Si stable isotopes (ascribed to core formation by Armytage et al., 2011), and also for V isotopes (Prytulak et al., 2013; Nielsen et al., 2014, reasons remain unclear). The similarity in mean $\delta^{60} \mathrm{Ni}$ between chondrites, iron meteorites and the BSE indicates that, in the case of Ni isotopes, core formation was not accompanied by any measurable isotope fractionation. This conclusion is consistent with the study by Lazar et al. (2012), based on solid metal-talc Ni isotope fractionation experiments. These authors found that even though the metal appears to be consistently slightly isotopically heavier than the silicate phase, the fractionation factor is minor at core-mantle boundary conditions $\left(\Delta^{60} \mathrm{Ni}_{\text {metal-talc }}=0.02 \%\right.$ at $\left.2500 \mathrm{~K}\right)$. The authors also noted that metal-silicate isotope fractionation appear to be temperature dependent. When using their expression for this $\left(\Delta^{62} \mathrm{Ni}_{\text {metal-talc }}=0.25( \pm 0.02)\right.$ $\times 10^{6} / \mathrm{T}^{2}( \pm 2$ s.e. $\left.)\right)$ to calculate the fractionation factor at mantle temperatures, $\Delta^{60} \mathrm{Ni}_{\text {metal-talc }}$ varies between 0.04 and $0.09 \%$ for temperatures from 1400 down to $900^{\circ} \mathrm{C}$ (Fig. 7). If the fractionation factor is based on our $\delta^{60} \mathrm{Ni}$ data for the BSE and iron meteorites (IM), $\Delta^{60} \mathrm{Ni}_{I M-B S E}$ becomes $0.056 \%$ ( \pm 0.06 ; s.d. $)$, which would correspond to a temperature of at least $1200^{\circ} \mathrm{C}$ (Fig. 7). The similarity in isotope composition for chondrites and 
iron meteorites furthermore implies that iron meteorites were all formed in equilibrium with silicate mantles at high temperatures, with no Rayleigh effects preserved. This supports the concept of magmatic iron meteorites being relict planetary cores and not impact melts.

\section{Conclusions}

1. Our data show that the upper mantle is variable in its Ni isotope composition, with a mean value of $0.23 \%$. $( \pm 0.13 \%$ o, 2 s.d.; $\mathrm{n}=66)$

2. There are systematic variations in $\delta^{60} \mathrm{Ni}$ between different mantle minerals, with olivine and orthopyroxene being significantly lighter than clinopyroxene, providing evidence that mantle $\mathrm{Ni}$ isotope compositions are controlled by differences in mineralogy caused by melt extraction and fractional crystallisation.

3. There is a relationship between $\delta^{57} \mathrm{Fe}$ and $\delta^{60} \mathrm{Ni}$ in ultramafic rocks related to mineralogy, with lower values of both isotope systems recorded in olivine-rich dunite and harzburgite and higher values shown in more fertile material.

4. Our best estimate for the $\delta^{60} \mathrm{Ni}_{B S E}$ is $0.23 \pm 0.06 \%$ based solely on lherzolite xenoliths and Phanerozoic komatiites. This is in good agreement 
with previously suggested values of Cameron et al. (2009) and Steele et al. (2011) but heavier than the value proposed by Gueguen et al. (2013).

5. Comparison between our BSE value and Ni isotope data for chondrite meteorites indicates that the BSE is chondritic and that core formation did not generate any measurable $\mathrm{Ni}$ isotope fractionation.

6. Iron meteorites generally display chondritic $\delta^{60} \mathrm{Ni}$, with a mean of $0.29 \pm 0.10 \%$. However, Duel Hill is very light $(-0.06 \pm 0.06 \%$, which is likely related to extreme fractional crystallisation associated with this sample.

\section{Acknowledgements}

We are indebted to all those who have supplied samples for this study. The Natural History Museum, London, and the Smithsonian National Museum of Natural History, Washington, are thanked for contributing meteorite samples, the late J.B. Dawson and Richard Herrington for peridotite samples. Thanks to Nick Belshaw, Theodor Krastev and Phil Holdship for their invaluable technical assistance with the analyses. We would like to thank

Tim Elliot and Ambre Luguet for their comments on earlier versions of the 
${ }_{555}$ manuscript. We would also like to thank the editor and three reviewers ${ }_{556}$ for their valuable comments and criticisms of the manuscript. We acknowl557 edge funding by Petrobras, the UK Science and Technology Facilities Council ${ }_{558}$ grant number ST/M001318/1 and the European Research Council Advanced 559 Fellowship Grant 247422 to ANH. HW acknowledges an ERC Starting Grant 560 (Habitable Planet; 306655) and a NERC Deep Volatiles Consortium Grant ${ }_{561}(\mathrm{NE} / \mathrm{M} 0003 / 1)$. 


\section{Figure and Table captions:}

Figure 1: The figure shows $\mathrm{Ni}$ isotope data for whole-rocks and mineral separates together with previously published data of peridotite reference materials and serpentinites. The smaller data points represent published Ni isotope data from Gueguen et al. $(2013)^{(1,2,8)}$ and Chernonozhkin et al. $(2015)^{(1,2,4)}$, Steele et al. $(2011)^{(3,4)}$, Ratié et al. $(2015)^{(5)}$, Estrade et al. $(2015)^{(6)}$, Gall et al. $(2013)^{(7)}$. The anomalous measurement of PCC-1 by Cameron et al. (2009), is not included in this comparison. A best estimate of the $\mathrm{Ni}$ isotope composition of the mantle, $\delta^{60} \mathrm{Ni}=0.23 \pm 0.06 \%$, is highlighted as the shaded area.

Figure 2: The figure shows the modal mineral abundances of olivine, orthopyroxene and clinopyroxene in the Tanzanian lherzolite and harzburgite xenoliths plotted against their whole-rock $\delta^{60} \mathrm{Ni}$ values. Clinopyroxene is highlighted separately on the right to demonstrate that a heavy isotope composition for whole rocks is likely due to a larger amount of isotopically heavy clinopyroxene.

Figure 3: $\delta^{60} \mathrm{Ni}$ plotted against $\delta^{57} \mathrm{Fe}$ for the Gorgona samples, the peridotite reference materials PCC-1, DTS-1, DTS-2, JP-1 and the spinel lherzolite P13 mineral separates. Nickel isotope data for DTS-2 and JP-1 are 
from Steele et al. (2011). Iron isotope data for PCC-1 and DTS-2 are from Dauphas et al. (2009), DTS-1 and JP-1 from Poitrasson et al. (2004), P13 and its mineral separates from Williams et al. (2009), and the komatiites and olivine cumulates from Hibbert et al. (2012). These data suggest a relationship between the two isotope systems in mantle rocks. All Fe isotope data can be found in a supplemental data table.

Figure 4: A summary of our Ni isotope data from mantle xenoliths, komatiites, cumulates and meteorites. The Ni isotope composition of the BSE, $\delta^{60} \mathrm{Ni}=0.23 \pm 0.06 \%$, is highlighted as the shaded area.

Figure 5: Comparison between meteorite data from this study and published data from Cameron et al. (2009); Steele et al. (2011, 2012); Gueguen et al. (2013); Chernonozhkin et al. (2015); Moynier et al. (2007); Cook et al. (2007). The chondrite data from Moynier et al. (2007) and Cook et al. (2007) are from metal separates, not whole-rock samples.

Figure 6: Nickel isotope composition of meteorites plotted against the $\mathrm{Ni}$ content and divided into meteorite class. Based on these data there appear to be a relationship between a ordinary chondrite metal content (class LL, L, H) and Ni isotope composition, apart from in sample Bruderheim.. Iron meteorites do not show a similar relationship between $\delta^{60} \mathrm{Ni}$ and class. The 
one very light iron meteorite sample (Duel Hill, $-0.06 \pm 0.06 \%$ ) contains up to twice the amount of $\mathrm{Ni}$ compared to the other iron meteorites.

Figure 7: Nickel isotope data from metal-talc experiments by Lazar et al. (2012) suggest that $\mathrm{Ni}$ isotope fractionation between metal and silicate is temperature dependant, with $\Delta^{60} \mathrm{Ni}_{\text {metal-talc }}$ being very small at normal mantle temperatures. Our data from iron meteorites (IM) and mantle rocks (BSE) give an average $\mathrm{Ni}$ isotope fractionation $\left(\Delta^{60} \mathrm{Ni}_{I M-B S E}\right)$ between these phases of $0.056 \%$ o $( \pm 0.12 \%, 2$ s.d.; the large error on this value is due to the propagation of errors on individual sample analyses), which would put the minimum exposure temperature for these samples to $\sim 1200^{\circ} \mathrm{C}$.

Table 1: Sample information and results for peridotite and komatiites analysed for their Ni isotope composition. Chemical as well as mineral compositions are taken from Dawson et al. (1970); Dawson and Smith (1972); Reid et al. (1975) for the mantle xenoliths and from Kerr et al. (1996) for the komatiites.

Table 2: Sample information and results for mineral separates from three lherzolite xenoliths from the Cameroon Line analysed for their Ni isotope composition. Modal mineral compositions are from Lee et al. (1996) and geochemical data from Williams et al. (2005). 
Table 3: Sample information and results for meteorites analysed for their $\mathrm{Ni}$ isotope composition. All samples analysed were from the Natural History Museum, London (BM) apart from three iron meteorites from the Smithsonian National Museum of Natural History, Washington D.C. (USNM). The Ni concentrations are published values for each meteorite: $a=$ Kallemeyn et al. (1989); $b=$ Morgan et al. (1985); $c=$ McSween (1977); $d=$ Hertogen et al. (1983); $e=$ Duke et al. (1961); $f=$ Jarosewich (1990); $g=$ Wasson (1969); $h=$ Buchwald (1975); $i=$ Goldberg et al. (1951); $j=$ Wasson and Richardson (2001); $k=$ Scott et al. (1973).

Supplementary material - Table 1: Iron isotope data $\left(\delta^{57} \mathrm{Fe}\right)$ of whole-rock and mineral samples used in Figure 3. 
W. F. McDonough, S. S. Sun, The composition of the Earth, Chemical Geology 120 (3-4) (1995) 223-253.

H. Palme, H. S. C. O'Neill, Cosmochemical estimates of mantle composition, in: R. W. Carlson (Ed.), Treatise on Geochemistry: The Mantle and Core, chap. 3.1, Elsevier Ltd., 2 edn., 1-38, 2014.

H. Sato, Nickel content of basaltic magmas: identification of primary magmas and a measure of the degree of olivine fractionation, Lithos 10 (1977) 113-120.

H. G. Stosch, Sc, Cr, Co and Ni partitioning between minerals from spinel peridotite xenoliths, Contributions to Mineralogy and Petrology 78 (2) (1981) 166-174.

W. A. Deer, R. A. Howie, J. Zussman, Rock Forming Minerals, vol. Vol. 1A and 2A, Longman, 2nd edn., 1982.

G. Witt-Eickschen, H. S. O'Neill, The effect of temperature on the equilibrium distribution of trace elements between clinopyroxene, orthopyroxene, olivine and spinel in upper mantle peridotite, Chemical Geology 221 (1-2) (2005) 65-101.

F. Kaminsky, Mineralogy of the lower mantle: a review of 'super-deep' mineral inclusion in diamond, Earth Science Reviews 110 (2012) 127-147.

D. J. Frost, C. Liebske, F. Langenhorst, M. C. A, Experimental evidence for the existence of iron-rich metal in the Earth's lower mantle, Nature 428 (2004) 409-412.

J. Wade, B. J. Wood, Core formation and the oxidation state of the Earth, Earth and Planetary Science Letters 236 (2005) 78-95. 
H. M. Williams, B. J. Wood, J. Wade, D. J. Frost, J. Tuff, Isotopic evidence for internal oxidation of the Earth's mantle during accretion, Earth and Planetary Science Letters 321-322 (2012) 54-63.

V. Cameron, D. Vance, C. Archer, C. H. House, A biomarker based on the stable isotopes of nickel, Proceedings of the National Academy of Sciences 106 (27) (2009) 10944-10948.

R. C. J. Steele, T. Elliott, C. D. Coath, M. Regelous, Confirmation of mass-independent $\mathrm{Ni}$ isotopic variability in iron meteorites, Geochimica et Cosmochimica Acta 75 (24) (2011) 7906-7925.

L. Gall, H. Williams, C. Siebert, A. Halliday, Determination of mass-dependent variations in nickel isotope compositions using double spiking and MC-ICPMS, Journal of Analytical Atomic Spectrometry 27 (2012) 137.

L. Gall, H. M. Williams, C. Siebert, A. N. Halliday, R. J. Herrington, J. R. Hein, Nickel isotopic compositions of ferromanganese crusts and the constancy of deep ocean inputs and continental weathering effects over the Cenozoic, Earth and Planetary Science Letters 375 (2013) 148-155.

B. Gueguen, O. Rouxel, E. Ponzevera, Nickel Isotope Variations in Terrestrial Silicate Rocks and Geological Reference Materials Measured by MC-ICP-MS, Geostandards and Geoanalytical Research (2013) doi: 10.1111/j.1751-908X.2013.00209.x.

S. M. Chernonozhkin, S. Goderis, L. Lobo, P. Claeys, F. Vanhaecke, Development of an isolation procedure and MC-ICP-MS measurement protocol for the study of stable 
isotope ratio variations of nickel, Journal of Analytical Atomic Spectrometry 30 (2015) $1518-1530$.

G. Ratié, D. Jouvin, J. Garnier, O. Rouxel, S. Miska, E. Guimarães, L. C. Vieira, Y. Sivry, I. Zelano, E. M. Pelletier, F. Thil, C. Quantin, Nickel isotope fractionation during tropical weathering of ultramafic rocks, Chemical Geology 402 (C) (2015) 68-76.

N. Estrade, C. Cloquet, G. Echevarria, T. Sterckeman, T. Deng, Y. Tang, J.-L. Morel, Weathering and vegetation controls on nickel isotope fractionation in surface ultramafic environments (Albania), Earth and Planetary Science Letters 423 (C) (2015) 24-35.

D. L. Cook, M. Wadhwa, R. N. Clayton, N. Dauphas, P. E. Janney, A. M. Davis, Massdependent fractionation of nickel isotopes in meteoritic metal, Meteoritics \& Planetary Science 42 (12) (2007) 2067-2077.

F. Moynier, J. Blichert-Toft, P. Télouk, J. M. Luck, Comparative stable isotope geochemistry of $\mathrm{Ni}, \mathrm{Cu}, \mathrm{Zn}$, and $\mathrm{Fe}$ in chondrites and iron meteorites, Geochimica et Cosmochimica Acta 71 (2007) 4365-4379.

R. C. J. Steele, C. D. Coath, M. Regelous, S. Russell, T. Elliott, Neutron-poor Nickel Isotope Anomalies in Meteorites, The Astrophysical Journal 758 (1) (2012) 59.

A. Hofmann, A. Bekker, P. Dirks, B. Gueguen, Comparing orthomagmatic and hydrothermal mineralization models for komatiite-hosted nickel deposits in Zimbabwe using multiple-sulfur, iron, and nickel isotope data, Mineralium Deposita .

S. J. Porter, D. Selby, V. Cameron, Characterising the nickel isotopic composition of organic-rich marine sediments, Chemical Geology 387 (2014) 12-21. 
V. Cameron, D. Vance, Heavy nickel isotope compositions in rivers and the oceans, Geochimica et Cosmochimica Acta 128 (2014) 195-211.

L. E. Wasylenki, H. D. Howe, L. J. Spivak-Birndorf, D. L. Bish, Ni isotope fractionation during sorption to ferrihydrite: Implications for $\mathrm{Ni}$ in banded iron formations, Chemical Geology 400 (C) (2015) 56-64.

J. B. Dawson, D. G. Powell, A. M. Reid, Ultrabasic Xenoliths and Lava from the Lashaine Volcano, Northern Tanzania, Journal of Petrology 11 (3) (1970) 519-548.

R. S. Cohen, R. K. O'Nions, J. B. Dawson, Isotope geochemistry of xenoliths from East Africa: implications for development of mantle reservoirs and their interaction, Earth and Planetary Science Letters 68 (1984) 209-220.

J. B. Dawson, Metasomatism and partial melting in upper-mantle peridotite xenoliths from the Lashaine volcano, northern Tanzania, Journal of Petrology 43 (2002) 1749-1777.

A. M. Reid, C. H. Donaldson, R. W. Brown, W. I. Ridley, J. B. Dawson, Mineral chemistry of peridotite xenoliths from the Lashaine volcano, Tanzania, Physics and Chemistry of the Earth 9 (1975) 525-543.

J. M. Rhodes, J. B. Dawson, Major and trace element chemistry of peridotite inclusions from the Lashaine volcano, Tanzania, Physics and Chemistry of the Earth 9 (1975) $545-557$.

J. B. Dawson, J. V. Smith, Alkalic Pyroxenite Xenoliths from the Lashaine Volcano, Northern Tanzania, Journal of Petrology 14 (1) (1972) 113-131. 
D. A. Carswell, J. B. Dawson, Garnet peridotite xenoliths in South African kimberlite pipes and their petrogenesis, Contributions to Mineralogy and Petrology 25 (1970) $163-184$.

J. L. Kulp, D. A. Brobst, Notes on the dunite and the geochemistry of vermiculite at the Day Book dunite deposit, Yancey County, North Carolina, Economic Geology 49 (3) (1954) 211-220.

A. M. Stueber, Abundances of $\mathrm{K}, \mathrm{Rb}, \mathrm{Sr}$ and $\mathrm{Sr}$ isotopes in ultramafic rocks and minerals from western North Carolina, Geochimica et Cosmochimica Acta 33 (1969) 543-553.

F. J. Flanagan, US Geological Survey silicate rock standards, Geochimica et Cosmochimica Acta 31 (1967) 289-308.

F. J. Flanagan, US Geological Survey standards II. First compilation of data for the new USGS rocks, Geochimica et Cosmochimica Acta 33 (1969) 81-120.

I. Barnes, J. R. O'Neil, The relationship between fluids in some fresh Alpine-Type ultramafics and possible modern serpentinization, Western United States. Geol. Soc. America Bulletin 80 (1969) 1947-1960.

D. M. Ragan, Emplacement of the Twin Sisters dunite, Washington, American Journal of Science 261 (1963) 549-565.

H. Williams, C. McCammon, A. H. Peslier, A. N. Halliday, N. Teutsch, S. Levasseur, J.-P. Burg, Iron Isotope Fractionation and the Oxygen Fugacity of the Mantle, Science 304 (2004) 1656-1659. 
H. Williams, A. Peslier, C. McCammon, A. Halliday, S. Levasseur, N. Teutsch, J. Burg, Systematic iron isotope variations in mantle rocks and minerals: The effects of partial melting and oxygen fugacity, Earth and Planetary Science Letters 235 (1-2) (2005) $435-452$.

D. C. Lee, A. N. Halliday, G. R. Davies, E. J. Essene, J. G. Fitton, R. Temdjim, Melt Enrichment of Shallow Depleted Mantle: a Detailed Petrological, Trace Element and Isotopic Study of Mantle-Derived Xenoliths and Megacrysts from the Cameroon Line, Journal of Petrology 37 (2) (1996) 415-441.

E. G. Nisbet, M. J. Cheadle, N. T. Arndt, M. J. Bickle, Constraining the potential temperature of the Archaean mantle: A review of the evidence from komatiites, Lithos $30(3-4)(1993)$ 291-307.

N. Arndt, C. M. Lesher, S. J. Barnes, Komatiite, Cambridge University Press, 2008.

N. Dauphas, F.-Z. Teng, N. T. Arndt, Magnesium and iron isotopes in 2.7 Ga Alexo komatiites: Mantle signatures, no evidence for Soret diffusion, and identification of diffusive transport in zoned olivine, Geochimica et Cosmochimica Acta 74 (11) (2010) $3274-3291$.

K. E. J. Hibbert, H. M. Williams, A. C. Kerr, I. S. Puchtel, Iron isotopes in ancient and modern komatiites: Evidence in support of an oxidised mantle from Archean to present, Earth and Planetary Science Letters 321-322 (2012) 198-207.

N. D. Greber, I. S. Puchtel, T. F. Nägler, K. Mezger, Komatiites constrain molybdenum 
isotope composition of the Earth's mantle, Earth and Planetary Science Letters 421 (C) (2015) 129-138.

P. S. Savage, F. Moynier, H. Chen, G. Shofner, J. Siebert, J. Badro, I. S. Puchtel, Copper isotope evidence for large-scale sulphide fractionation during Earth?s differentiation, Geochemical Perspectives Letters, 1 (2015) 53-64.

R. J. Walker, M. Storey, A. C. Kerr, J. Tarney, N. T. Arndt, Implications of ${ }^{187}$ Os isotopic heterogeneities in a mantle plume: evidence from Gorgona Island and Curaçao, Geochimica et Cosmochimica Acta 63 (5) (1999) 713-728.

C. W. Sinton, R. A. Duncan, M. Storey, J. Lewis, J. J. Estrada, An oceanic flood basalt province within the Caribbean plate, Earth and Planetary Science Letters $155(3-4)$ (1998) 221-235.

B. G. Aitken, L. M. Echeverría, Petrology and geochemistry of komatiites and tholeiites from Gorgona Island, Colombia, Contributions to Mineralogy and Petrology 86 (1) (1984) 94-105.

N. T. Arndt, A. C. Kerr, J. Tarney, Dynamic melting in plume heads: the formation of Gorgona komatiites and basalts, Earth and Planetary Science Letters 146 (1-2) (1997) $289-301$.

A. C. Kerr, G. F. Marriner, N. T. Arndt, J. Tarney, A. Nivia, A. D. Saunders, R. A. Duncan, The petrogenesis of Gorgona komatiites, picrites and basalts: new field, petrographic and geochemical constraints, Lithos 37 (2-3) (1996) 245-260. 
A. C. Kerr, La Isla de Gorgona, Colombia: A petrological enigma?, Lithos 84 (1-2) (2005) $77-101$.

J. W. Gramlich, E. S. Beary, L. A. Machlan, I. L. Barnes, The absolute isotopic composition and atomic weight of terrestrial nickel, Journal of Research of the National Institute of Standards and Technology 94 (6) (1989) 357.

C. Siebert, T. F. Nägler, J. D. Kramers, Determination of molybdenum isotope fractionation by double-spike multicollector inductively coupled plasma mass spectrometry, Geochemistry Geophysics Geosystems 2 (7) (2001) doi: 10.1029/2000GC000124.

N. Dauphas, P. R. Craddock, P. D. Asimow, V. C. Bennett, A. P. Nutman, D. Ohnenstetter, Iron isotopes may reveal the redox conditions of mantle melting from Archean to Present, Earth and Planetary Science Letters 288 (1-2) (2009) 255-267.

C. Lazar, E. D. Young, C. E. Manning, Experimental determination of equilibrium nickel isotope fractionation between metal and silicate from $500^{\circ} \mathrm{C}$ to $950^{\circ} \mathrm{C}$, Geochimica et Cosmochimica Acta 86 (C) (2012) 276-295.

N. Imai, S. Terashima, S. Itoh, A. Ando, 1994 compilation values for GSJ reference samples, "Igneous rock series"., Geochemical Journal 29 (1) (1995) 91-95.

F. Poitrasson, A. N. Halliday, D. C. Lee, S. Levasseur, N. Teutsch, Iron isotope differences between Earth, Moon, Mars and Vesta as possible records of contrasted accretion mechanisms, Earth and Planetary Science Letters 223 (3-4) (2004) 253-266.

N. Dauphas, M. Roskosz, E. E. Alp, D. R. Neuville, M. Y. Hu, C. K. Sio, F. L. H. Tissot, J. Zhao, L. Tissandier, E. Medard, C. Cordier, Magma redox and structural controls 
on iron isotope variations in Earth's mantle and crust, Earth and Planetary Science Letters 398 (2014) 127-140.

H. M. Williams, M. Bizmis, Iron isotope tracing of mantle heterogeneity within the source regions of oceanic basalts, Earth and Planetary Science Letters 404 (2014) 396-407.

M. Duke, D. Maynes, H. Brown, The petrography and chemical composition of the Bruderheim meteorite, Journal of Geophysical Research 66 (10) (1961) 3557-3563.

J. T. Wasson, J. W. Richardson, Fractionation trends among IVA iron meteorites: Contrasts with IIIAB trends, Geochimica et Cosmochimica Acta 65 (6) (2001) 951-970.

M. I. Smoliar, R. J. Walker, M. J. W, Re-Os ages of group IIA, IIIA, IVA and IVB iron meteorites, Science 271 (1996) 1099-1102.

P. Bonnand, H. M. Williams, I. J. Parkinson, W. B. J, A. N. Halliday, Stable chromium isotopic composition of meteorites and metal-silicate experiments: implications for fractionation during core formation, Earth and Planetary Science Letters 435 (2015) 14-21.

R. C. Hin, C. Burkhardt, M. W. Schmidt, B. Bourdon, T. Kleine, Experimental evidence for Mo isotope fractionation between metal and silicate liquids, Earth and Planetary Science Letters 379 (2013) 38-48.

C. Burkhardt, R. C. Hin, T. Kleine, B. Bourdon, Evidence for Mo isotope fractionation in the solar nebula and during planetary differentiation, Earth and Planetary Science Letters 391 (2014) 201-211. 
F. Moynier, Q.-Z. Yin, E. Schauble, Isotopic Evidence of Cr Partitioning into Earth's Core, Science 331 (6023) (2011) 1417-1420.

R. M. G. Armytage, R. B. Georg, P. S. Savage, H. M. Williams, A. N. Halliday, Silicon isotopes in meteorites and planetary core formation, Geochimica et Cosmochimica Acta 75 (13) (2011) 3662-3676.

J. Prytulak, S. G. Nielsen, D. A. Ionov, A. N. Halliday, J. Harvey, K. A. Kelley, Y. L. Niu, D. W. Peate, K. Shimizu, K. W. W. Sims, The stable vanadium isotope composition of the mantle and mafic lavas, Earth and Planetary Science Letters 365 (C) (2013) $177-189$.

S. G. Nielsen, J. Prytulak, B. J. Wood, A. N. Halliday, Vanadium isotopic difference between the silicate Earth and meteorites, Earth and Planetary Science Letters 389 (2014) $167-175$.

H. M. Williams, S. G. Nielsen, C. Renac, W. L. Griffin, S. Y. O'Reilly, C. A. McCammon, N. Pearson, F. Viljoen, J. C. Alt, A. N. Halliday, Fractionation of oxygen and iron isotopes by partial melting processes: Implications for the interpretation of stable isotope signatures in mafic rocks, Earth and Planetary Science Letters 283 (1-4) (2009) $156-166$.

G. W. Kallemeyn, A. E. Rubin, D. Wang, Ordinary chondrites: Bulk compositions, classification, lithophile-element fractionations and composition-petrographic type relationships, Geochimica et Cosmochimica Acta 53 (10) (1989) 2747-2767. 
J. W. Morgan, M. J. Janssens, H. Takahashi, H-chondrites: Trace element clues to their origin, Geochimica et Cosmochimica Acta 49 (1) (1985) 247-259.

H. Y. McSween, Carbonaceous chondrites of the Ornans type: a metamorphic sequence, Geochimica et Cosmochimica Acta 41 (4) (1977) 477-491.

J. Hertogen, M. J. Janssens, H. Takahashi, Enstatite chondrites: trace element clues to their origin, Geochimica et Cosmochimica Acta 47 (12) (1983) 2241-2255.

E. Jarosewich, Chemical analyses of meteorites: A compilation of stony and iron meteorite analyses, Meteoritics \& Planetary Science 25 (4) (1990) 323-337.

J. T. Wasson, The chemical classification of iron meteorites-III. Hexahedrites and other irons with germanium concentrations between 80 and 200 ppm, Geochimica et Cosmochimica Acta 33 (1969) 859-876.

V. F. Buchwald, Handbook of iron meteorites, their history, distribution, composition, and structure, Center for Meteorite Studies, Arizona State University, 1975.

E. Goldberg, A. Uchiyama, H. Brown, The distribution of nickel, cobalt, gallium, palladium and gold in iron meteorites, Geochimica et Cosmochimica Acta 2 (1) (1951) $1-25$.

E. R. D. Scott, J. T. Wasson, V. F. Buchwald, The chemical classification of iron meteorites-VII. A reinvestigation of irons with Ge concentrations between 25 and $80 \mathrm{ppm}$, Geochimica et Cosmochimica Acta 37 (8) (1973) 1957-1983. 


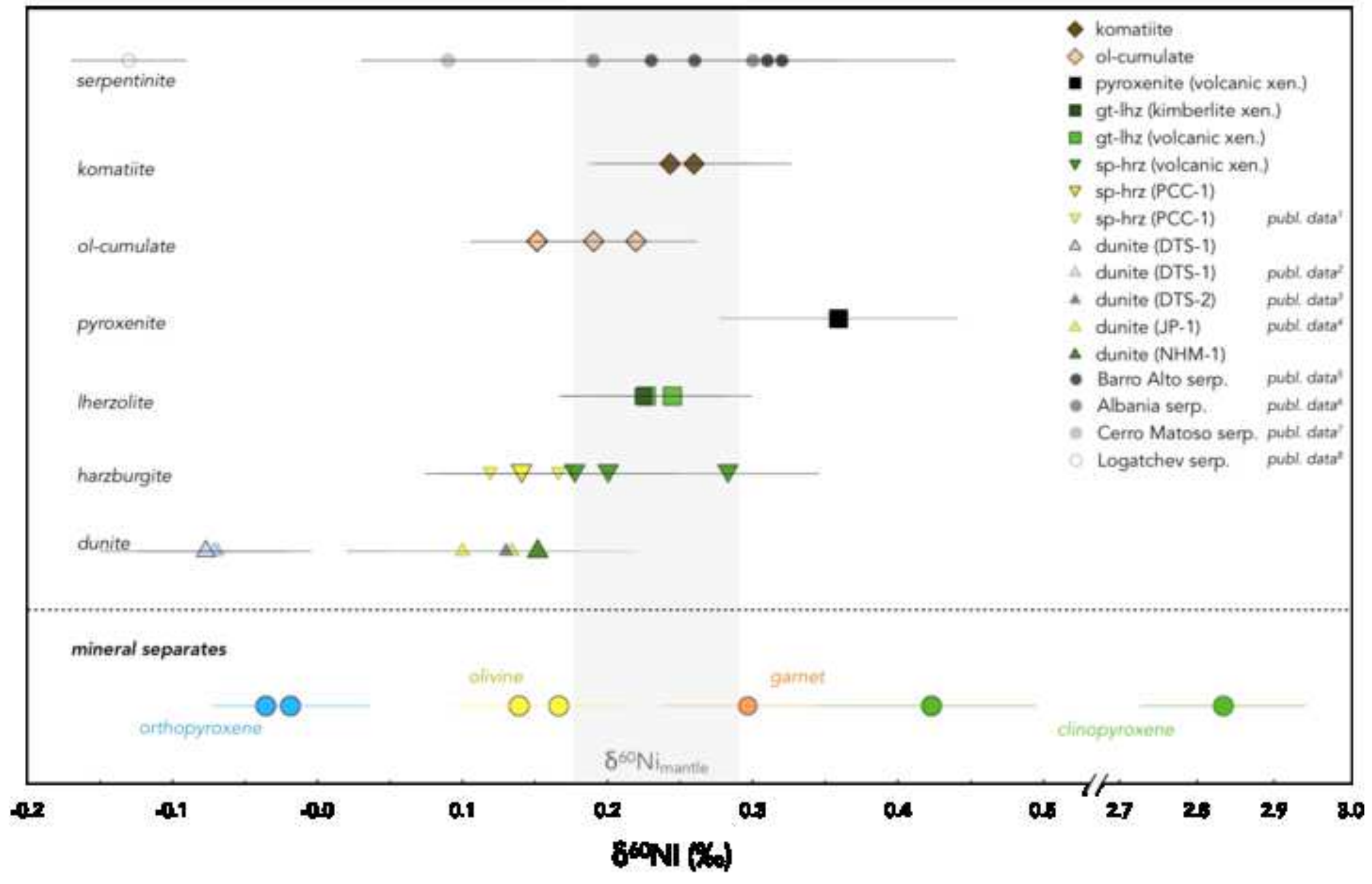




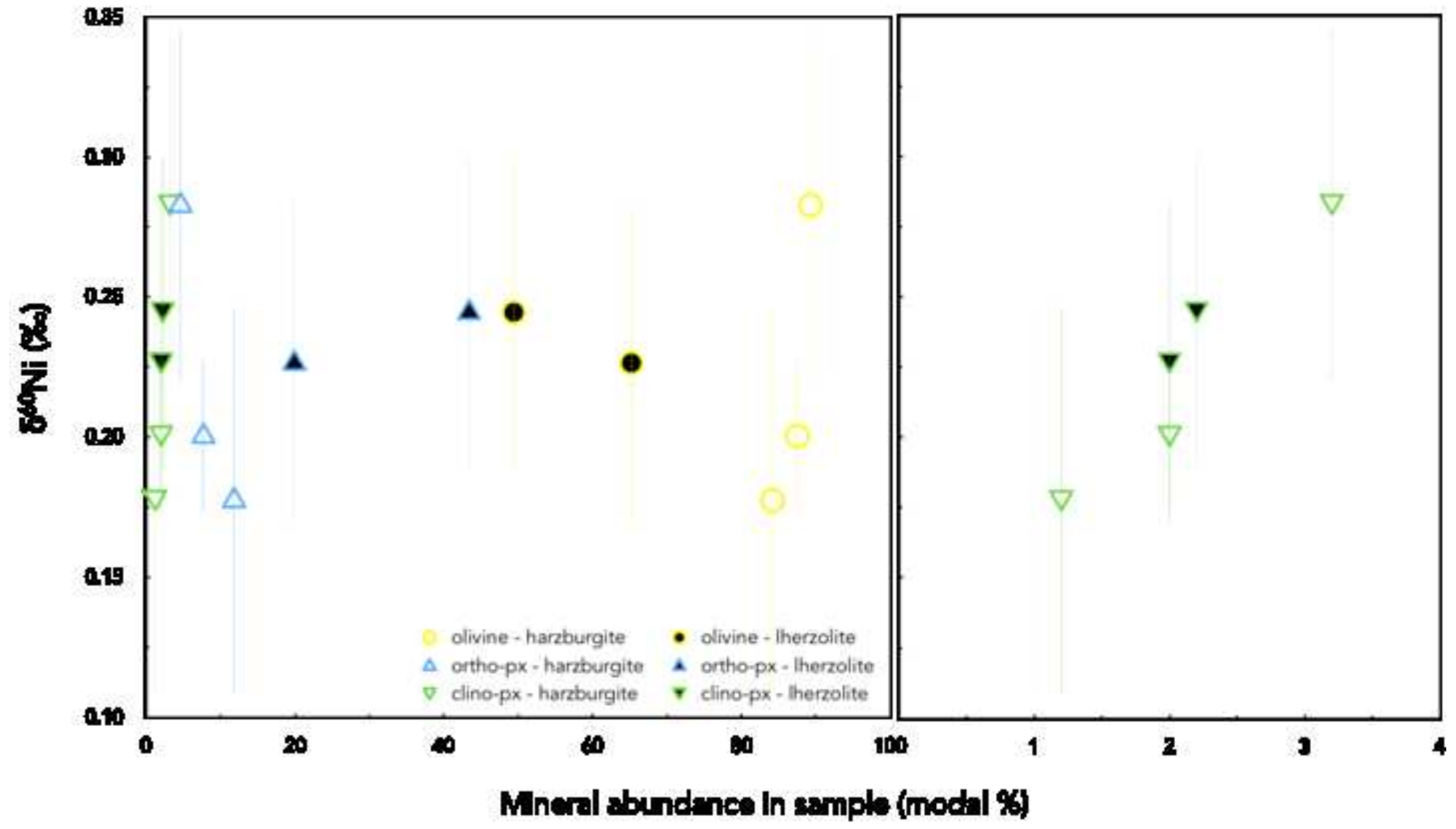




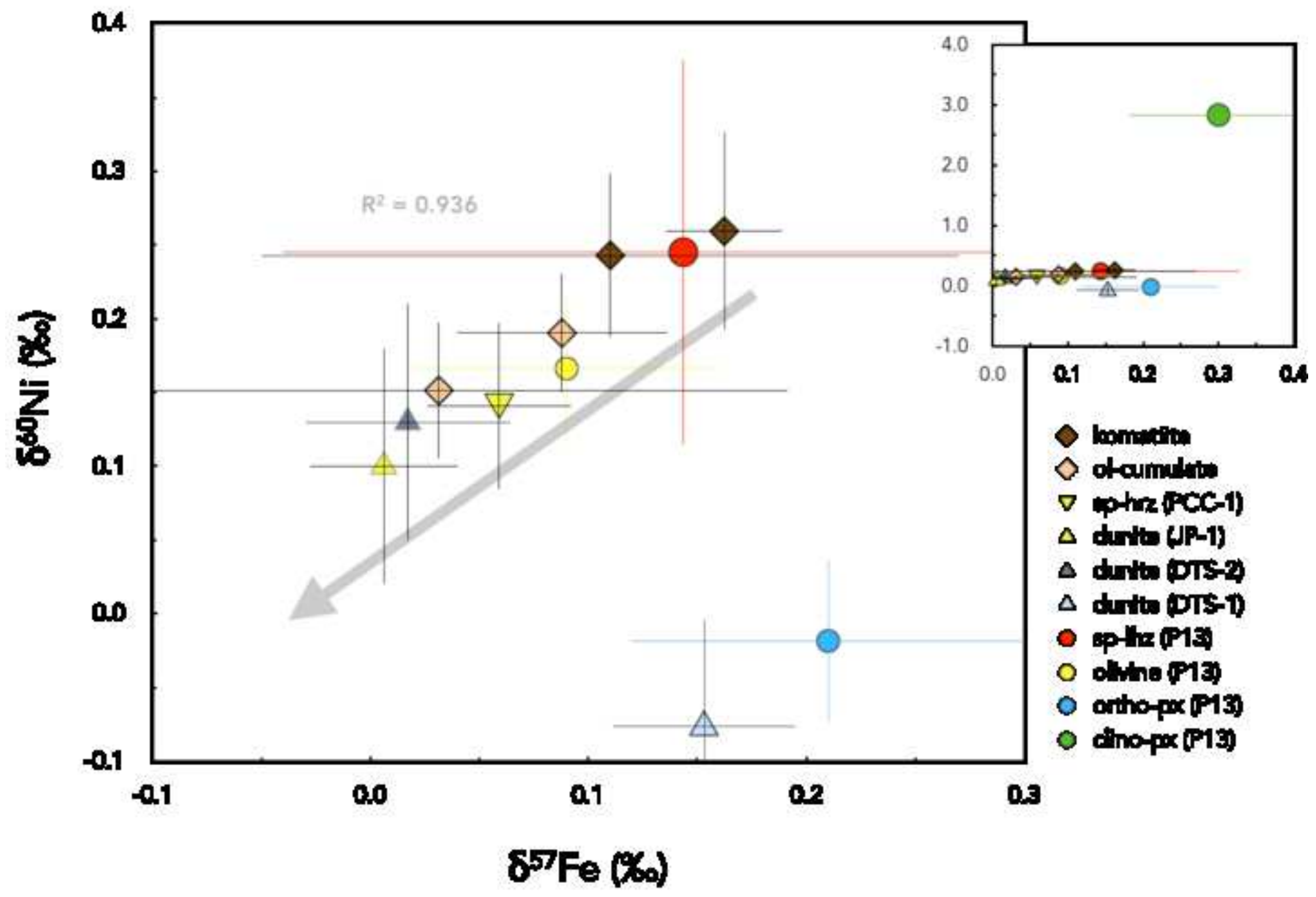




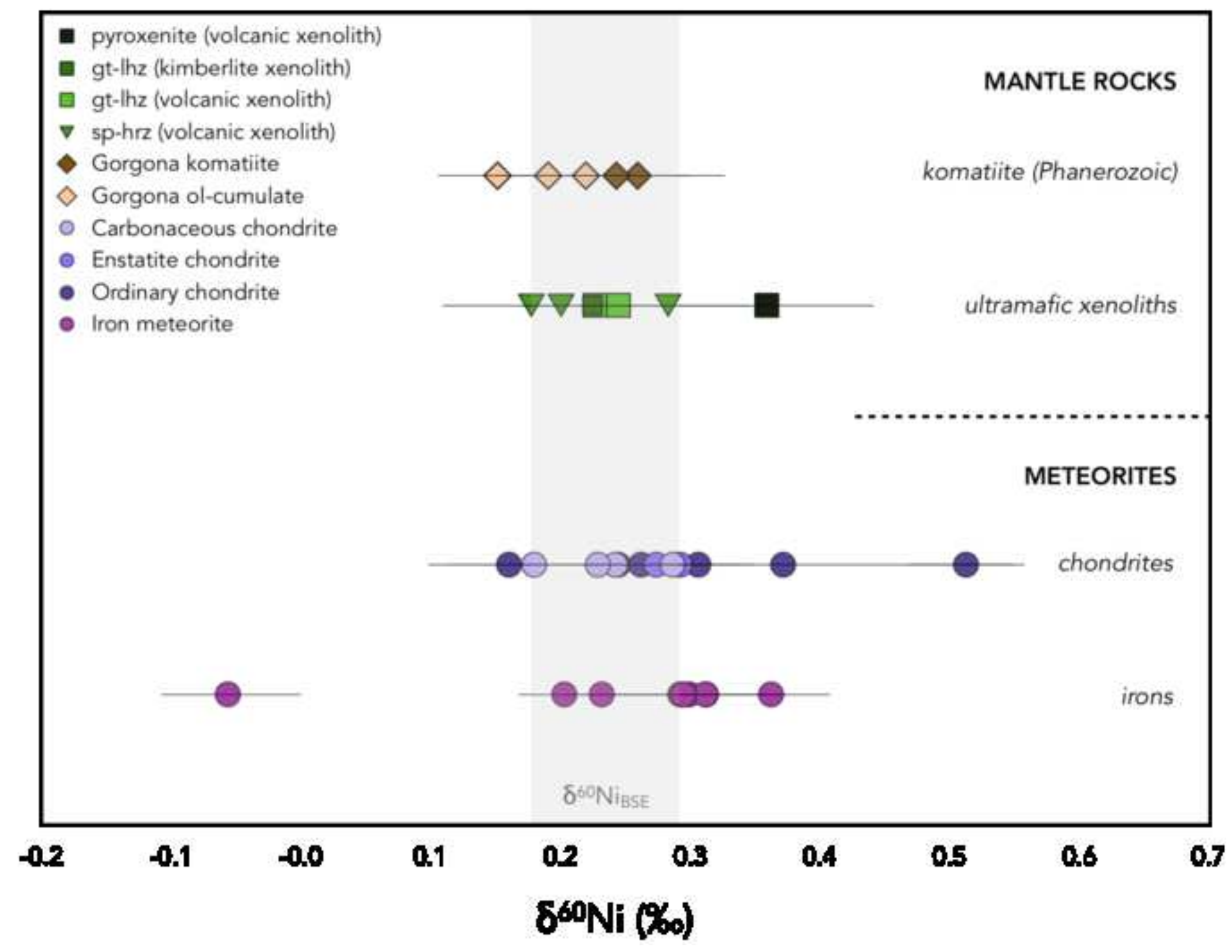




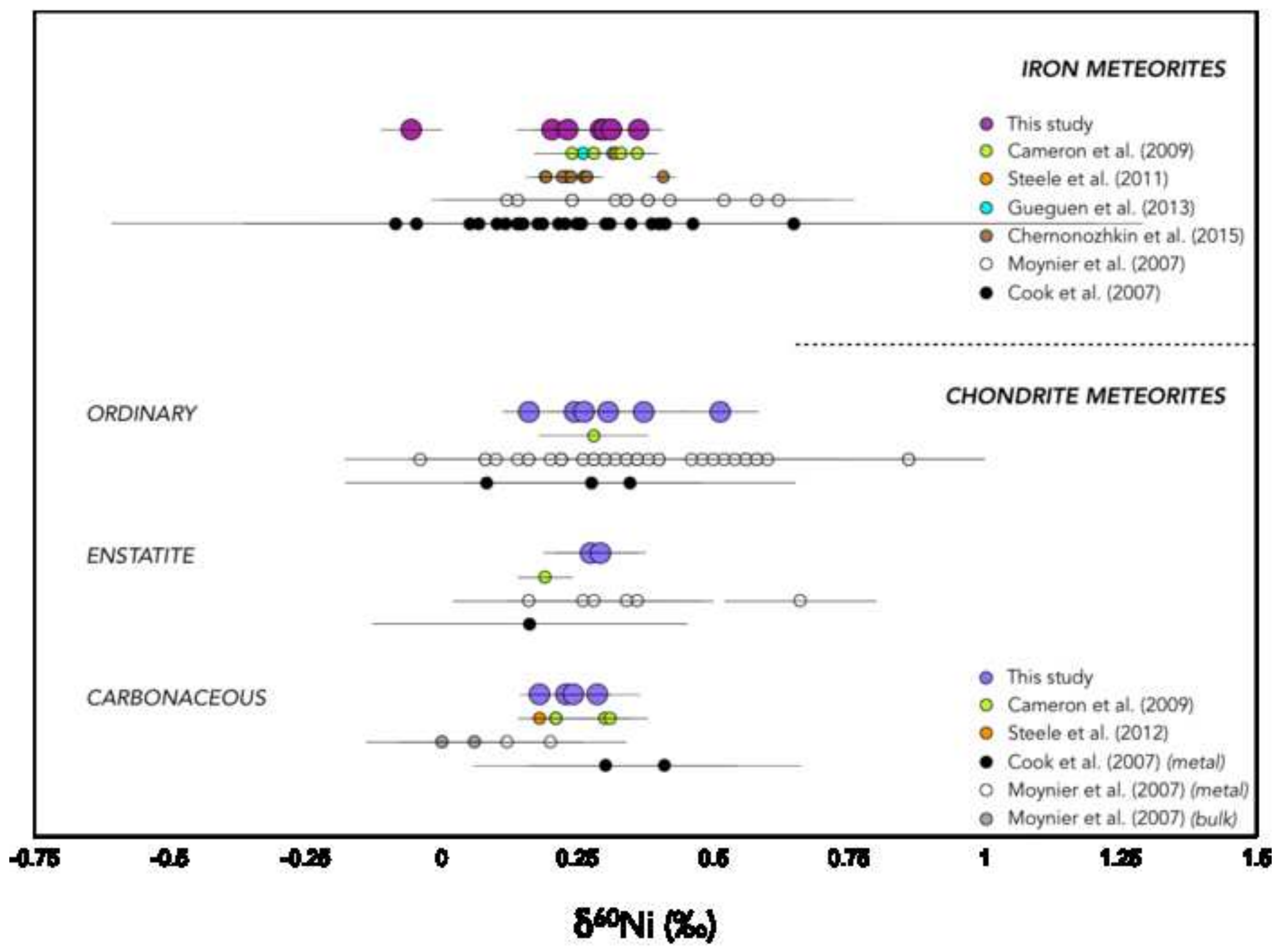




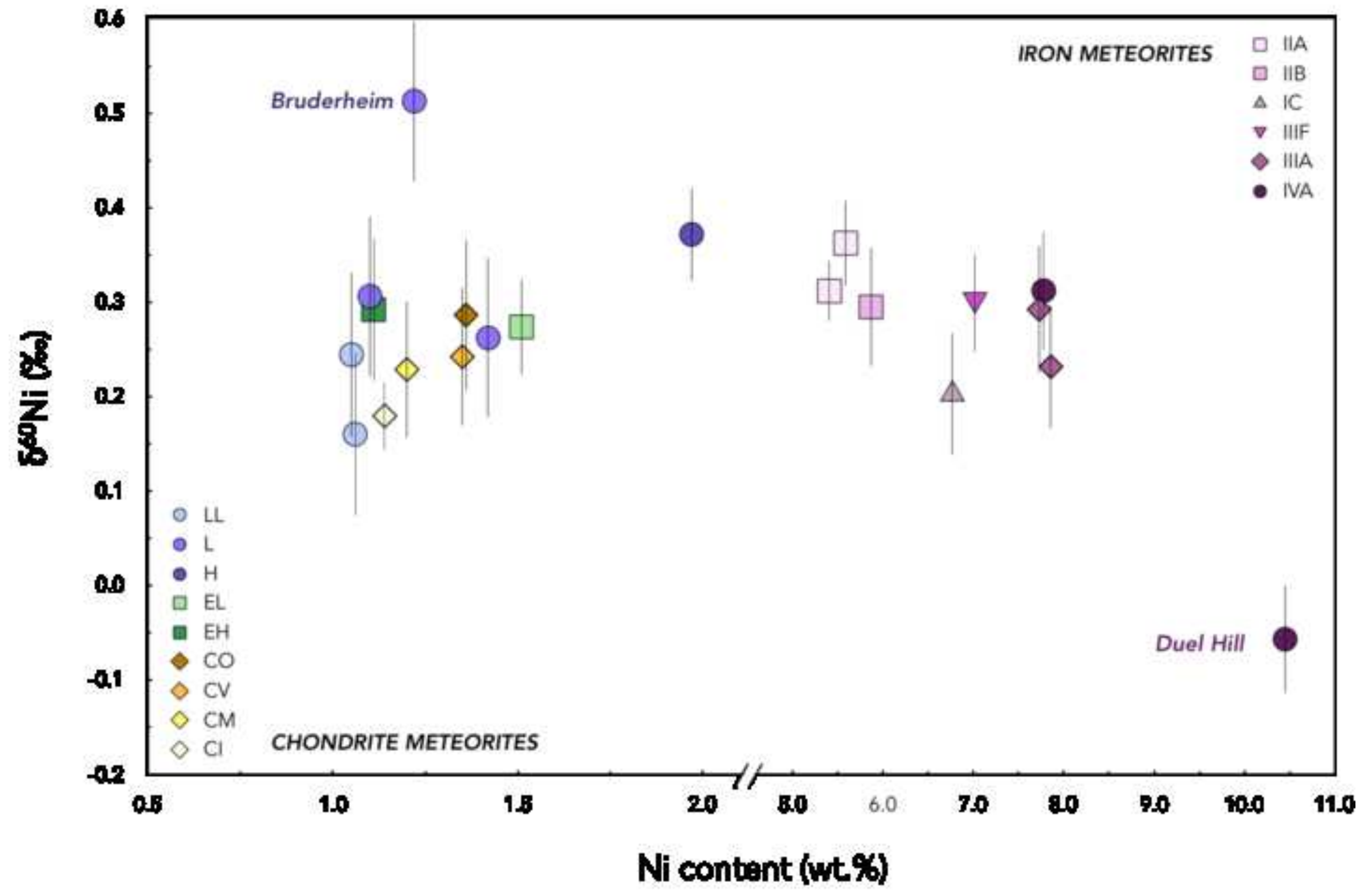




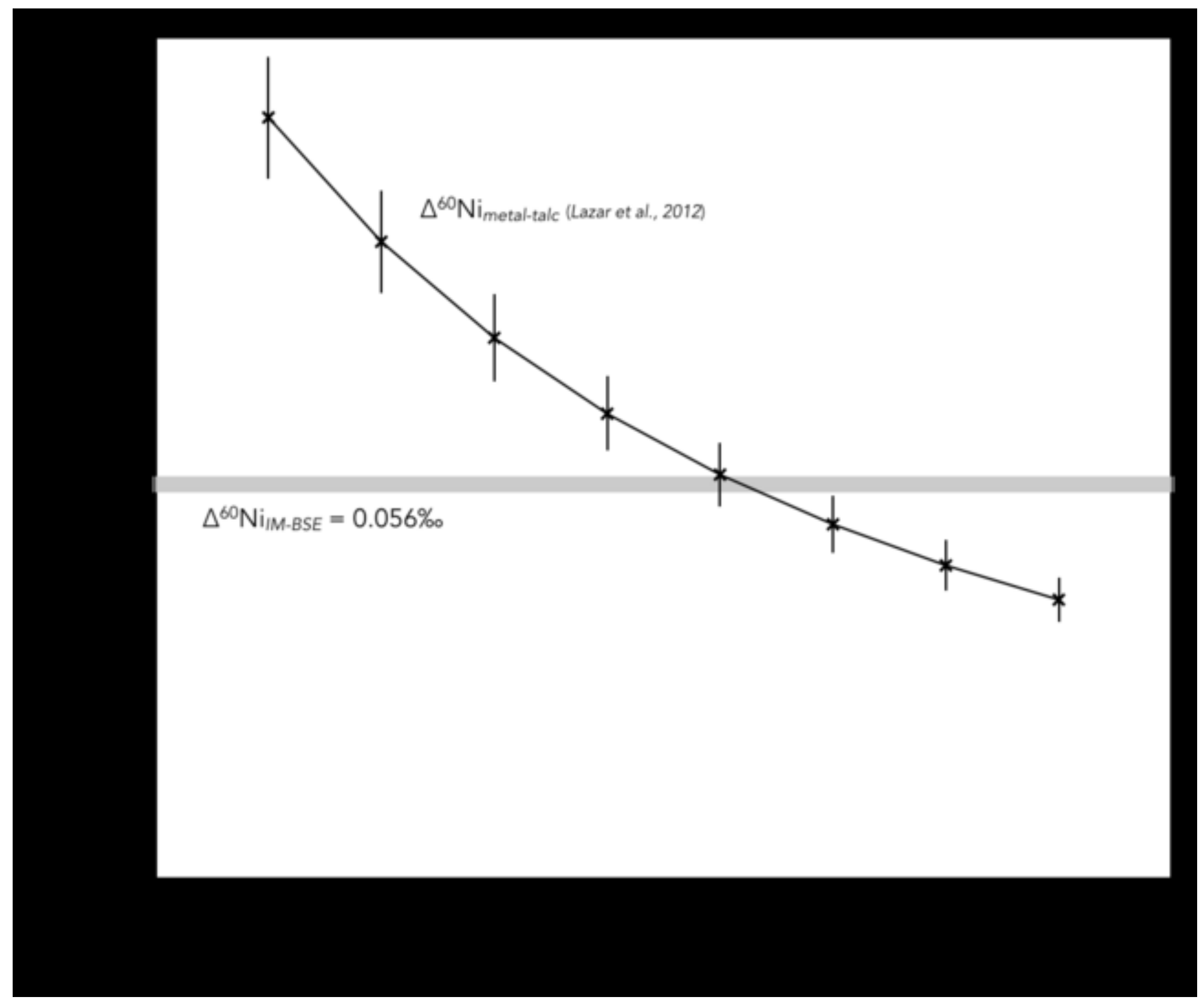


Table 1

\begin{tabular}{|c|c|c|c|c|c|c|c|c|}
\hline Sample & Origin & Rock type & Mineralogy (modal \%) & $\delta^{60} \mathbf{N i}(\%$ o $)$ & \pm 2 s.d. & $n$ & $\mathrm{Ni}(\mu \mathrm{g} / \mathrm{g})$ & $\mathrm{Mg \#}$ \\
\hline \multicolumn{9}{|l|}{ Peridotites } \\
\hline DTS-1 & Washington, USA & orogenic, dunite & $\mathrm{ol}, \mathrm{sp}$ & -0.077 & 0.073 & 32 & 2360 & 0.92 \\
\hline PCC-1 & California, USA & orogenic, harzburgite & ol, opx, cpx, sp & 0.141 & 0.056 & 17 & 2325 & 0.91 \\
\hline NHM-1 & North Carolina, USA & orogenic, dunite & $\mathrm{ol}, \mathrm{sp}$ & 0.152 & 0.069 & 9 & 2830 & \\
\hline \multicolumn{9}{|c|}{ Ultramafic xenoliths } \\
\hline NHM-2 & South Africa & kimberlite xenolith, lherzolite & ol, opx, cpx, gt & 0.224 & 0.058 & 6 & 1740 & \\
\hline BD744 & Lashaine, Tanzania & volcanic xenolith, pyroxenite & $\mathrm{ol}, \mathrm{cpx}, \mathrm{mica}, \mathrm{sp}$ & 0.359 & 0.082 & 3 & 2700 & 0.92 \\
\hline BD822 & Lashaine, Tanzania & volcanic xenolith, harzburgite & ol $(84.2)$, opx (11.8), cpx (1.2), sp (0.4) & 0.177 & 0.069 & 6 & 2345 & 0.93 \\
\hline BD1542 & Lashaine, Tanzania & volcanic xenolith, harzburgite & ol $(87.5)$, opx $(7.7), \operatorname{cpx}(2.0), \mathrm{sp}(0.8)$ & 0.200 & 0.027 & 3 & 2500 & 0.92 \\
\hline BD774 & Lashaine, Tanzania & volcanic xenolith, harzburgite & ol (89.3), opx (4.6), cpx (3.2), sp (0.2) & 0.283 & 0.063 & 6 & 2165 & 0.92 \\
\hline BD730 & Lashaine, Tanzania & volcanic xenolith, lherzolite & ol (65.2), opx (19.9), cpx (2.0), gt (12.9) & 0.226 & 0.057 & 6 & 1880 & 0.92 \\
\hline BD1355 & Matsoka, Tanzania & volcanic xenolith, lherzolite & ol (49.4), opx (43.4), cpx, (2.2), gt (3.6) & 0.245 & 0.055 & 3 & 2100 & 0.93 \\
\hline \multicolumn{9}{|c|}{ Phanerozoic komatiites } \\
\hline GOR 94-3 & Gorgona, Colombia & olivine cumulate & ol, plag, cpx, sp, glass & 0.219 & 0.042 & 3 & 1575 & 0.84 \\
\hline GOR 94-17 & Gorgona, Colombia & olivine cumulate & ol, plag, cpx, sp, glass & 0.151 & 0.046 & 3 & 1110 & 0.81 \\
\hline GOR 94-44 & Gorgona, Colombia & olivine cumulate & ol, plag, cpx, sp, glass & 0.190 & 0.040 & 4 & 1325 & 0.82 \\
\hline GOR 94-19 & Gorgona, Colombia & G1 komatiite & ol, plag, cpx, sp, glass & 0.259 & 0.067 & 3 & 1080 & 0.78 \\
\hline GOR 94-43 & Gorgona, Colombia & G1 komatiite & ol, plag, cpx, sp, glass & 0.243 & 0.055 & 4 & 1200 & 0.81 \\
\hline
\end{tabular}


Table 2

\begin{tabular}{|c|c|c|c|c|c|c|c|c|}
\hline Sample & Origin & Mineral & Modal (\%) & $\delta^{60} \mathrm{Ni}(\% \mathrm{oo})$ & \pm 2 s.d. & $n$ & $\mathbf{N i}(\mu \mathrm{g} / \mathrm{g})$ & $\mathrm{Mg} \#$ \\
\hline $\begin{array}{l}\text { C273Q } \\
\text { (lherzolite) }\end{array}$ & $\begin{array}{l}\text { Lake Enep, } \\
\text { Cameroon }\end{array}$ & olivine & $\begin{array}{l}\text { ol: } 45 \% \\
\text { opx: } 35 \% \\
\text { cpx: } 15 \% \\
\text { sp: } 5 \%\end{array}$ & 0.139 & 0.044 & 4 & 2870 & $\mathrm{n} / \mathrm{a}$ \\
\hline $\begin{array}{l}\text { C235A } \\
\text { (lherzolite) }\end{array}$ & $\begin{array}{l}\text { Lake Baronbi Mbo, } \\
\text { Cameroon }\end{array}$ & orthopyroxene & $\begin{array}{l}\text { opx: } 25 \% \\
\text { ol: } 60 \% \\
\text { cpx: } 10 \% \\
\text { sp: } 5 \%\end{array}$ & -0.035 & 0.031 & 5 & 785 & 0.90 \\
\hline $\begin{array}{l}\text { P13 } \\
\text { (lherzolite) }\end{array}$ & $\begin{array}{l}\text { Ngaoundere Plateau, } \\
\text { Cameroon }\end{array}$ & $\begin{array}{l}\text { olivine } \\
\text { orthopyroxene } \\
\text { clinopyroxene }\end{array}$ & $\begin{array}{l}\text { ol: } 65 \% \\
\text { opx: } 25 \% \\
\text { cpx: } 5 \% \\
\text { sp: } 5 \%\end{array}$ & $\begin{array}{c}0.166 \\
-0.019 \\
2.834\end{array}$ & $\begin{array}{l}0.049 \\
0.055 \\
0.108\end{array}$ & $\begin{array}{l}5 \\
4 \\
3\end{array}$ & $\begin{array}{c}3150 \\
770 \\
455\end{array}$ & $\begin{array}{l}0.89 \\
0.90 \\
0.94\end{array}$ \\
\hline $\begin{array}{l}\text { N12 } \\
\text { (harzburgite) }\end{array}$ & $\begin{array}{l}\text { Biu Plateau, } \\
\text { Cameroon }\end{array}$ & $\begin{array}{l}\text { clinopyroxene } \\
\text { garnet }\end{array}$ & $\begin{array}{l}\text { ol: } 55-60 \% \\
\text { opx: } 40-45 \%\end{array}$ & $\begin{array}{l}0.423 \\
0.296\end{array}$ & $\begin{array}{l}0.078 \\
0.060\end{array}$ & $\begin{array}{l}5 \\
5\end{array}$ & $\begin{array}{l}395 \\
160\end{array}$ & $\begin{array}{l}\mathrm{n} / \mathrm{a} \\
\mathrm{n} / \mathrm{a}\end{array}$ \\
\hline
\end{tabular}


Table 3

\begin{tabular}{|c|c|c|c|c|c|c|c|}
\hline Sample & Number & Type & Class & $\delta^{60} \mathbf{N i}(\%)$ & \pm 2 s.d. & $n$ & $\mathrm{Ni}$ (wt.\%) \\
\hline \multicolumn{8}{|c|}{ Chondrite meteorites } \\
\hline Allende & BM 1969.148 & carbonaceous & CV3 & 0.242 & 0.073 & 9 & $1.35^{a}$ \\
\hline Murchinson & BM 17016 & carbonaceous & $\mathrm{CM} 2$ & 0.229 & 0.072 & 9 & $1.20^{b}$ \\
\hline Ornans & BM 42474 & carbonaceous & $\mathrm{CO} 3$ & 0.286 & 0.079 & 4 & $1.36^{c}$ \\
\hline Orgueil & BM 36104 & carbonaceous & CI1 & 0.180 & 0.036 & 4 & $1.14^{d}$ \\
\hline Indarch & BM 86948 & enstatite & EH4 & 0.274 & 0.087 & 9 & $1.11^{a}$ \\
\hline Khaipur & BM 1985.M144 & enstatite & EL6 & 0.292 & 0.084 & 9 & $1.29^{a}$ \\
\hline Kernouve & BM 43400 & ordinary & H6 & 0.372 & 0.075 & 4 & $1.97^{b}$ \\
\hline Bremervorde & BM 33910 & ordinary & H3 & 0.262 & 0.050 & 5 & $1.42^{a}$ \\
\hline Baratta & BM 1925.1286 & ordinary & $\mathrm{L} 4$ & 0.306 & 0.046 & 9 & $1.10^{a}$ \\
\hline Bruderheim & BM 1967.256 & ordinary & L6 & 0.513 & 0.071 & 5 & $1.22^{e}$ \\
\hline Parnallee & BM 34792 & ordinary & LL3 & 0.160 & 0.049 & 4 & $1.06^{a}$ \\
\hline St Severin & BM 1866.493 & ordinary & LL6 & 0.244 & 0.047 & 5 & $10.5^{f}$ \\
\hline \multicolumn{8}{|c|}{ Iron meteorites } \\
\hline Negrillos & USNM 1222 & hexahedrite & IIA & 0.312 & 0.032 & 6 & $5.41^{g}$ \\
\hline North Chile & BM 1959.917 & hexahedrite & IIA & 0.362 & 0.045 & 6 & $5.59^{h}$ \\
\hline Arispe & USNM 2638 & coarse octahedrite & IC & 0.203 & 0.064 & 5 & $6.77^{i}$ \\
\hline Clark County & BM 1959.949 & medium octahedrite & IIIF & 0.299 & 0.051 & 6 & $7.02^{i}$ \\
\hline Duel Hill & USNM 1048 & fine octahedrite & IVA & -0.057 & 0.057 & 6 & $10.45^{j}$ \\
\hline Gibeon & BM 1910.753 & fine octahedrite & IVA & 0.312 & 0.062 & 6 & $7.78^{j}$ \\
\hline Sikhte-Alin & BM 1992.M37 & coarse octahedrite & IIB & 0.295 & 0.062 & 6 & $5.87^{g}$ \\
\hline Charcas & BM 85075 & medium octahedrite & IIIA & 0.232 & 0.065 & 6 & $7.86^{k}$ \\
\hline Henbury & BM 1932.1473 & medium octahedrite & IIIA & 0.292 & 0.067 & 6 & $7.47^{i}$ \\
\hline
\end{tabular}

